\title{
Projekt Kruh prstenu aneb antropologie sexuality: Zdeněk Macháček
}

\author{
Jaroslav Malina \\ Ústav antropologie Přírodovědecké fakulty Masarykovy Univerzity, Vinařská 5, 60300 Brno
}

Projekt Kruh prstenu: Světové dějiny sexuality, erotiky a lásky od počátkư do současnosti v reálném životě, krásné literatuře, výtvarném umění a dílech českých malírư a sochařư inspirovaných obsahem této knihy vznikl počátkem devadesátých let minulého století. Představuje vytvoření reprezentativní trojsvazkové publikace a sbírky erotik českých malírủ a sochařun.

Trilogii tvoří tyto tři svazky:

Kruh prstenu, 1: „Celý svět" kromě euroamerické civilizace (2007);

Kruh prstenu, 2: Euroamerická civilizace (2013);

Kruh prstenu, 3: Český svět (2015).

Autorem námětu a celého projektu je Jaroslav Malina, spoluautory jsou Marie Dohnalová, Jan Filipský, Helena Honcoopová, Blahoslav Hruška, Josef Kandert, Oldřich Kašpar, Josef Kolmaš, Miroslav Králík, Adéla Křikavová, Olga Lomová, Miriam Löwensteinová, Klára Macúchová, Giuseppe Maiello, Jakub Maršálek, Jaroslav Oliverius, Lucie Olivová, Alena Opletalová, Marie Pardyová, Jiří Pavelka, Lydia Petráňová, Ivo Pospíšil, Jaroslav Skupnik, Jiří A. Svoboda, Miloš Štědroň, Hana Tř́sková, Břetislav Vachala, Václav Vančata, Marina Vančatová, František Vrhel, Jaroslav Zvěřina, tedy přední čeští amerikanisté, antropologové, arabisté, archeologové, egyptologové, etnologové, historici, indologové, japanisté, koreanisté, literární historici, indologové, sexuologové, sinologové, sumerologové, tibetologové a další odborníci. Kruh prstenu předkládá pojednání o vývoji lidské sexuality, erotiky, lásky a manželství v biologických, obecně antropologických a kulturně historických souvislostech spolu s přehlídkou nejzajímavějších literárních a výtvarných děl minulosti a zároveň přináší reprodukce obrazů, grafik, soch a plastik, jež v závěru 20. a počátkem 21. století vytvořilo více než sedm desítek českých malî́r̊n, grafiků a sochařů inspirovaných obsahem jednotlivých svazků trilogie.

Trilogie Kruh prstenu je patrně prvním pokusem zachytit takové základní hodnoty života člověka a společnosti, jakými jsou sexualita, erotika, láska a manželství, a to celostně, na multidisciplinárním základě, integrovaném prostředky moderní biologické a sociokulturní antropologie i v inspirujícím sepětí vědy a umění.

Vzniklo dílo celostní a zdá se, že i ojedinělé.

V jednotlivých číslech časopisu Anthropologia integra budou uveřejňovány medailony zúčastněných výtvarníků a reprodukovány některé z jejich artefaktů vytvořených pro projekt Kruh prstenu.

Dnes: sochař Zdeněk Macháček (je autorem sochařského emblému Kruh prstenu; jeho nejčerstvějším dílem je sochařský emblém Encyklopedie antropologie).

\section{ZDENĚK MACHÁČEK}

Lidská sexualita, erotika a láska prolínají celým sochařským dílem Zdeňka Macháčka, měníce se v průběhu takřka šedesátileté tvůrčí dráhy $\mathrm{v}$ souladu s vývojem a proměnami jeho výtvarného jazyka a s přibývajícími životními zkušenostmi. Jeho př́íklon ke zmíněnému tématu se ještě prohloubil, když byl v roce 1996 vyzván $\mathrm{k}$ výtvarné účasti na projektu tř́isvazkové knihy a výstavy Kruh prstenu: Světové dějiny sexuality, erotiky a lásky od počátkư do současnosti $v$ reálném životě, krásné literatuře, výtvarném umění a dilech českých malǐru a sochařů inspirovaných obsahem této knihy (Jaroslav Malina a kolektiv).

Macháčkovo dílo pro tento projekt je mimořádné. Ukázalo se totiž, že dané téma je mu velmi blízké, ba možná nejbližší - nebot v letech 1996-2008 nejenže vytvořil pro tento projekt několik desítek plastik (včetně trojrozměrného emblému Kruh prstenu), ale napsal k některým $\mathrm{z}$ nich neobyčejně vtipné a jazykově vybroušené komentáře. Je zřejmé, že slova a češtinu dokáže obrábět a soustružit stejně mistrně a s láskou jako svůj základní sochařský materiál.

Zdeněk Macháček se narodil 16. srpna 1925 v Brně. Po ab- 


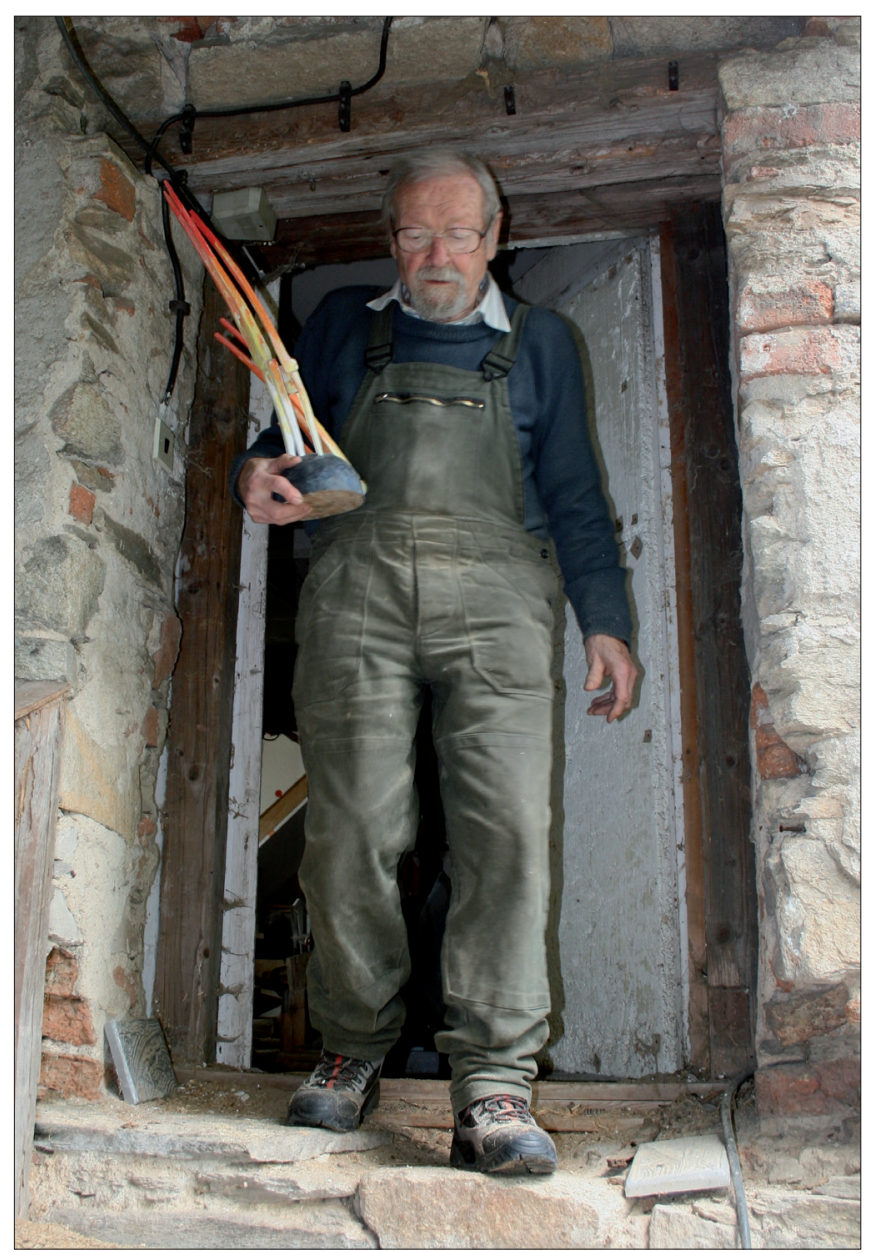

Obr. 1. Sochař Zdeněk Macháček (2010). Foto: Stáňa Bártová. Sculptor Zdeněk Macháček (2010).

Bildhauer Zdeněk Macháček (2010).

solvování reálného gymnázia studoval v letech 1945 až 1947 obory zoologie a antropologie na Přírodovědecké fakultě Masarykovy univerzity $\mathrm{v}$ Brně. Po třech letech musel školu $\mathrm{z}$ „kádrových důvodů“ (rodina vlastnila grafický závod) opustit a z týchž důvodů nebyl přijat na Vysokou školu uměleckoprůmyslovou v Praze. V roce 1952 absolvoval Vyšší školu uměleckého průmyslu v Brně. Po studiích byl krátce zaměstnán, od roku 1961 je na „Volné noze“. Nejprve působil v Brně, poté, v roce 1971, odchází do Křížovic u Doubravníku, kde žije a tvoří podnes. V roce 1958 se stal jedním ze zakládajících členů skupiny Parabola, je členem brněnského tvůrčího Sdružení Q a Horáckého klubu výtvarných umělců. Spoluzaložil mezinárodní sochařské sympozium Dřevěná plastika ve Ždáru nad Sázavou a je jeho hlavním organizátorem.

V polovině padesátých let Zdeněk Macháček vstoupil do českého umění - nejprve ovšem do úzkého okruhu brněnského výtvarného dění - jako sochař, jehož údělem se stalo především dřevo. V pracích $\mathrm{z}$ konce padesátých a počátku šedesátých let má významné místo série komorních patinovaných dřevořezeb s náměty zvířat. K charakteristickým patří opakující se motiv býka, jehož sevřený, oblý tvar má v sobě prvek skryté síly a dynamiky. Zjednodušená forma pomíjí popisné
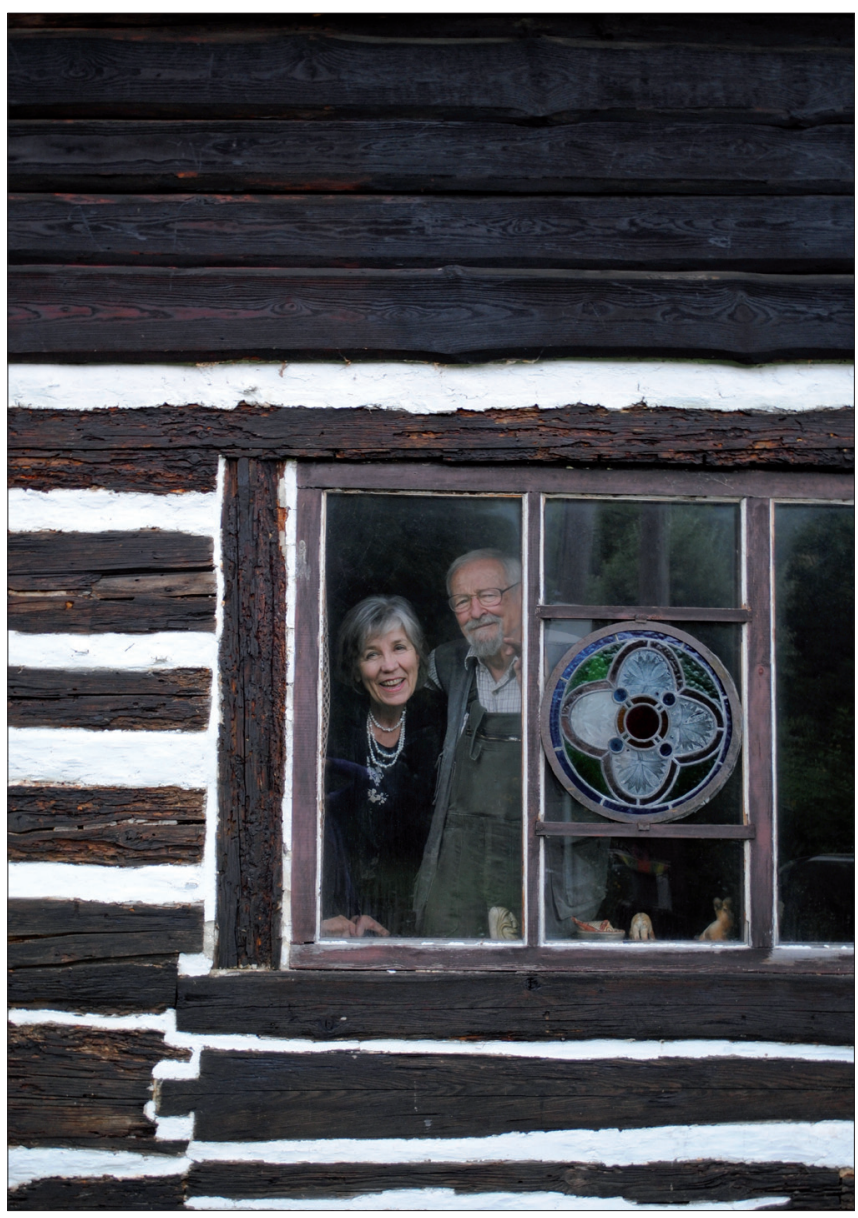

Obr. 2. Zdeněk Macháček s manželkou Stanislavou Macháčkovou (2010). Foto: Stáňa Bártová.

Zdeněk Macháček with his wife Stanislava Macháčková in Křížovice (2010). Zdeněk Macháček mit seiner Frau Stanislava Macháčková in Křížovice (2010)

detaily a přes nevelké rozměry prozrazuje smysl pro monumentalitu. Je to však tvorba nesporné výtvarné hodnoty, jež vynikne tím více, srovnáváme-li ji s velkou částí běžné produkce padesátých let v českém umění. Především pak obsahuje některé principy či náznaky těch rysů, kterými se v různých údobích vyznačuje sochařovo zralé dílo.

Počátkem šedesátých let nastává $\mathrm{v}$ jeho tvorbě významný zvrat: řadu zvírecích plastik, většinou malých rozměrů, střídá cyklus ženských postav - Venuší - a se změnou námětu přichází i proměna sochařského vyjádření, které se výrazněji vzdaluje od vnější shody s předmětnou skutečností. V novém ztvárnění figury a v ženských torzech se autorův živý smysl pro tvar a objem stále stupňuje, aby se pak znovu uplatnil $\mathrm{v}$ pozdějších letech, $\mathrm{v}$ návratech $\mathrm{k}$ tomuto věčnému tématu. Postupně vyvinul autonomní formu, jen vzdáleně připomínající figuru: stylizované, plně plastické postavy tvoří jakousi schránku kolem vnitřního jádra nebo je štíhlý dř́k s ňadry obklopen pouzdrem s vyhloubeným vnitřním prostorem. Tento princip vybírání hmoty a tím vytváření obalu kolem prázdného prostoru patří v různých údobích a v rozmanitých podobách $\mathrm{k}$ příznačným rysům Macháčkova výtvarného stylu. Vznikají první práce pro veřejné prostory, které se stanou 


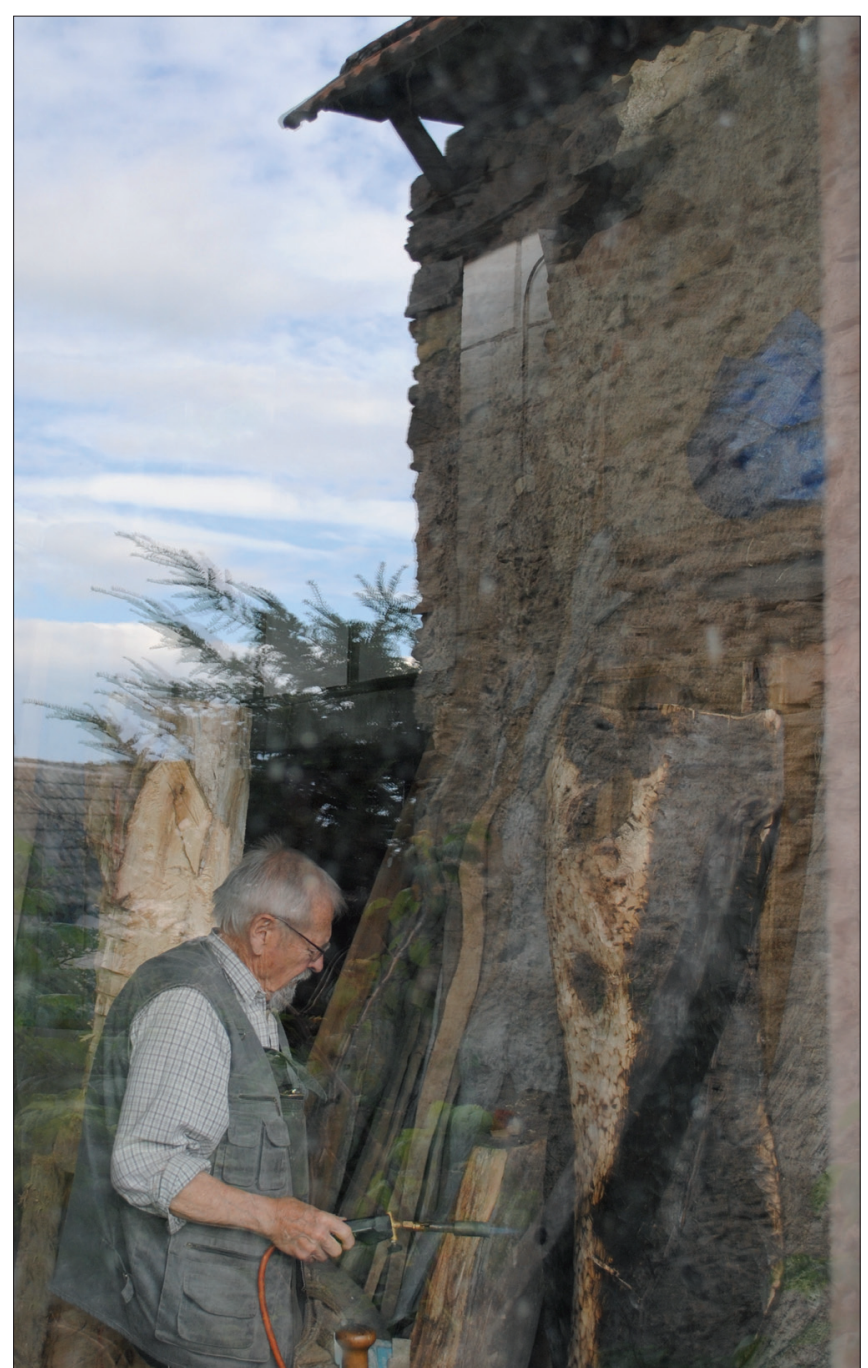

Obr. 3. Ateliér Zdeňka Macháčka v Křížovicích (2010). Foto: Stáňa Bártová. Studio of Zdeněk Macháček in Křrižovice (2010).

Atelier von Zdeněk Macháček in Kř́žovice (2010).

velmi významnou součástí Macháčkovy tvorby. $V$ šedesátých letech k nim patří zejména Plastiky zviŕat (1961, Pavilon Anthropos Moravského zemského muzea v Brně-Pisárkách), Ptáci (1966, areál brněnského výstaviště v Brně-Pisárkách), Př́roda a člověk (1968, areál Ústavu pro další vzdělávání středních zdravotnických pracovníků v Brně-Pisárkách [dnes Národní centrum ošetřovatelství a nelékařských zdravotnických oborů]) aj.

V průběhu šedesátých let byla série Venuší vystřídána, či spíše paralelně provázena řadou prací zcela odlišných, nazvaných Světy ticha. K jejich vzniku přispěl objev, jemuž autor za mnohé vděčí, totiž zvláštní prostředí pod vodní hladinou, které jako potápěč důvěrně poznal. Světy ticha znamenají $\mathrm{v}$ umělcově tvorbě novou kvalitu. Zásadní proměnou je nejen prechod od figurální tematiky $\mathrm{k}$ novým, $\mathrm{z}$ př́rody čerpaným a abstraktně ztvárněným motivům, ale opět i nové sochařské postupy. Hmota se stává vnějším obalem kolem vyhloubeného jádra. Bizarní, štíhlé protáhlé vertikální útvary tvoří kontrast $\mathrm{k}$ formě kulovité, spirálově stočené. Vnějšś schránka může být

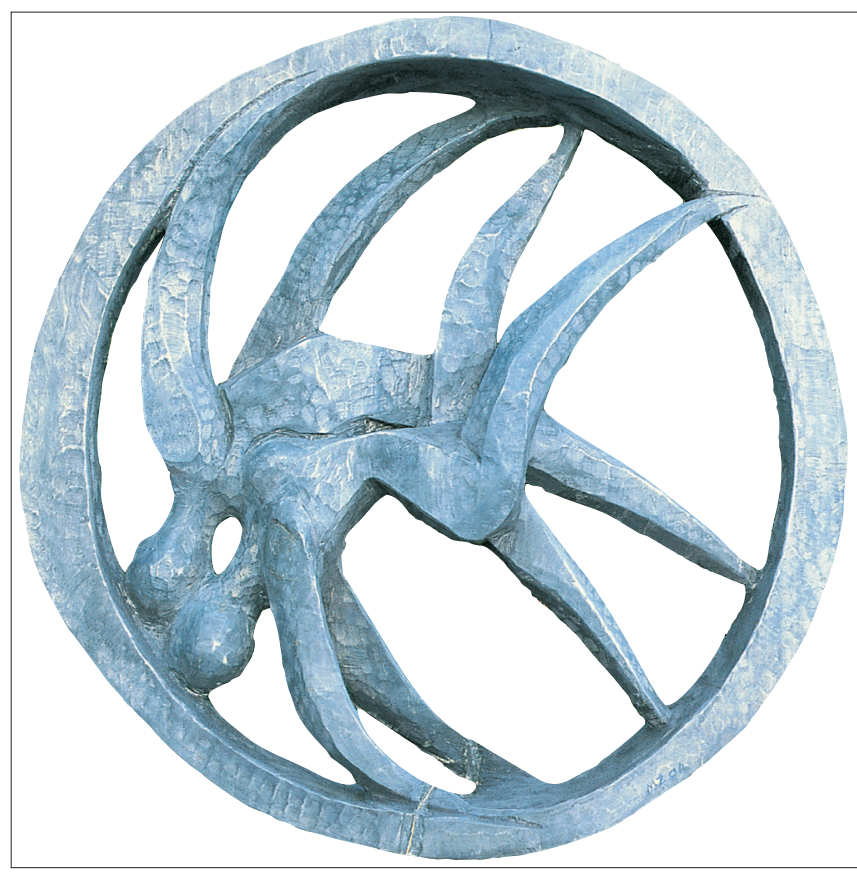

Obr. 4. Kruh prstenu, 2004, mořený topol, průměr $99 \mathrm{~cm}$, výška (s podstavcem) $158 \mathrm{~cm}$. Trojrozměrný emblém projektu Kruh prstenu. Foto: Jitka Havlová.

A Cycle of a Ring, 2004, stained poplar, perimeter $99 \mathrm{~cm}$, height (with the pedestal) $158 \mathrm{~cm}$. Tridimensional emblem of the project A Cycle of a Ring.

Der Kreis des Fingerringes, 2004, Pappel gebeizt, Durchschnitt $99 \mathrm{~cm}$, Höhe (samt Gestell) $158 \mathrm{~cm}$. Dreidimensionales Emblem zum Projekt Der Kreis des Fingerringes.

i uzavřenou klíckou, jejímiž otvory nahlížíme do nitra, které skrývá další plastický tvar. Vzniká dojem křehkých skořápek, vyvolaný místy maximálně ztenčeným objemem dřevěného pláště, jenž halí i odkrývá vnitřní sochařský prostor. Vnější obrys jednotlivých forem je hladce plynulý, jakoby ohlazený mořem. Ve Světech ticha kulminuje Macháčkova tvorba první poloviny šedesátých let. Jeho vztah $\mathrm{k}$ prrírodě tu našel výraz velmi osobní a smysl pro práci se dřevem dosáhl virtuozity, aniž by opustil vlastní povahové znaky materiálu. Po Světech ticha poutá Zdeňka Macháčka i nadále svět prírody. Proti jejich křehké, esteticky propracované a dematerializované abstrakci mají nové motivy lapidárně tesaný, hmotný objem. Výmluvným vyjádřením umělcova vztahu $\mathrm{k}$ tematické oblasti, k níž se upíral jeho intenzivní zájem, je trojdílná skupina Př́roda a člověk (1968), instalovaná v Brně-Pisárkách (areál Ústavu pro další vzdělávání středních zdravotnických pracovníkủ v Brně-Pisárkách [dnes Národní centrum ošetřovatelství a nelékařských zdravotnických oborů]). Dva vysoké sloupové objekty, připomínající totemy, jsou na celé ploše povrchu bohatě strukturovány. Kontrast tvoří nízká, kulovitá, uvnitř vyhloubená plastika představující srdce se stylizovanými artériemi. Toto Macháčkovo první exteriérové ve dřevě realizované dílo je mimořádné jak svým nepopisným sdělením dané ideje, tak působivě volenou skladbou hmot - vysokých vertikál a nízké kulovité formy, jejíž umělecký účin si sochař ověřil již na Světech ticha. Oba vznosné sloupy jsou vlastně počátkem dlouhé řady sochařsky ztvárněných kmenů lesních stromů, jež tvoří náplň jedné z významných autorových tvůrčích etap. 


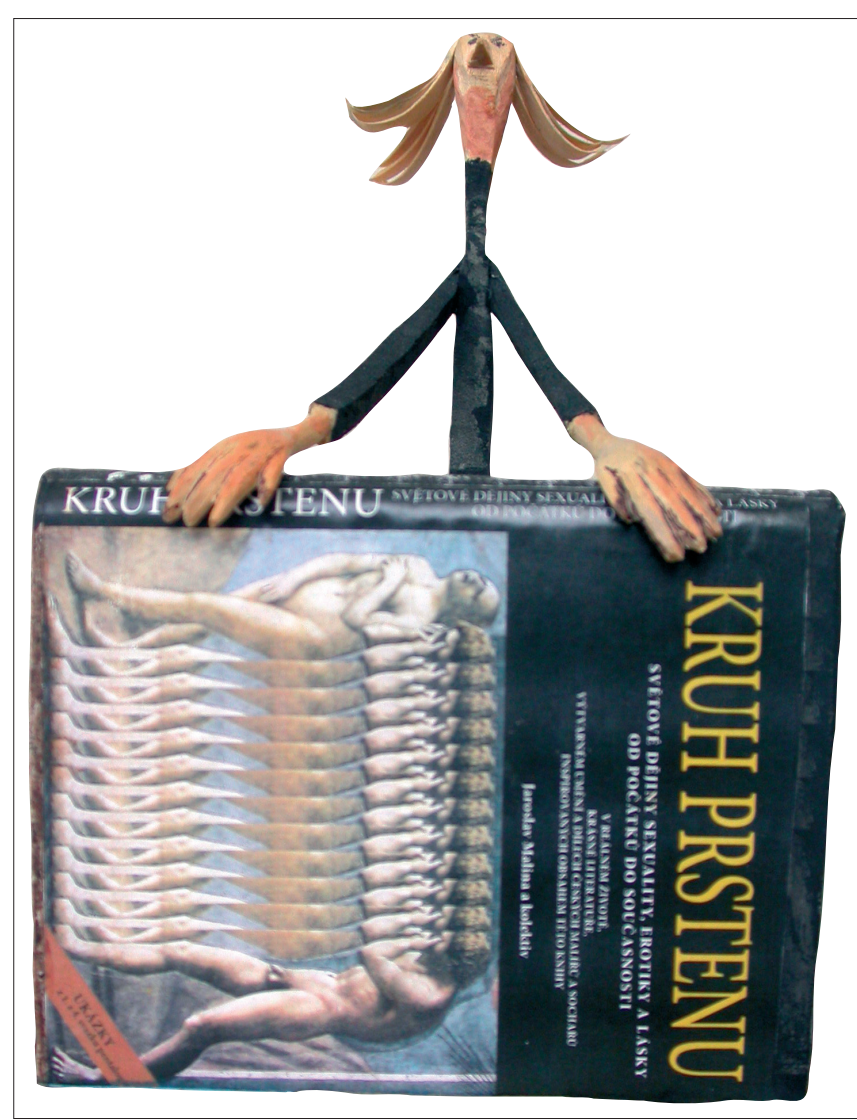

Obr. 5. Kruh prstenu pro JM, 2004, polychromovaná lípa, výška $21 \mathrm{~cm}$. Foto: Jitka Havlová.

A Cycle of a Ring for JM, 2004, polychromatic linden, height $21 \mathrm{~cm}$.

Der Kreis des Fingerringes für JM, 2004, Linde polychromiert, Höhe $21 \mathrm{~cm}$.

V letech 1964-1969 podniká každoroční studijní cesty do Itálie. Z hlubokých prožitků italské krajiny i historických měst vznikl cyklus zvláštních objektů - Italská města, tvořených pevným jádrem obklopeným srostlicemi kubických tvarů. Bez náznaků jakékoliv personifikace či symbolů je v nich čistě sochařskými prostředky vyjádřeno umělcovo vnímání charakteru jednotlivých měst, jejich uspořádání i zasazení v krajině. K vyjádření těchto dojmů a pocitů i poznání, jež tu pro sebe objevil, vyvinul sochař vlastní formotvorné tvarosloví, společné cyklu italských měst jako celku, přitom však odrážející odlišnosti různých lokalit. V zásadě jde o velké, nepravidelně opracované bloky kontrastující s menšími útvary. Výtvarný nápad rozvinutý v cyklu italských měst uplatnil autor v jiné podobě i ve své nové tvưrčí a životní etapě, jejímž dějištěm se stala nevelká ves Kř́ž́ovice.

V roce 1971 přesídlil do Křížovic u Doubravníku, kde žije podnes. Tento rok znamená předěl v umělcově životě i tvorbě. Poloha Kř́ížovic v kopcovité krajině vysočinského podhůří, stranou hlavních cest je jak novým impulzem, tak potvrzením autorových starších uměleckých východisek. Př́roda, která jej tu obklopuje, se stává trvalou součástí života i díla. Tak jako donedávna ztvárňoval svůj osobitý vjem italských měst, $v$ němž se uplatňoval smysl pro monumentální členění hmot, tak se nyní v cyklu Kř́žovice upíná k drobnému mě-

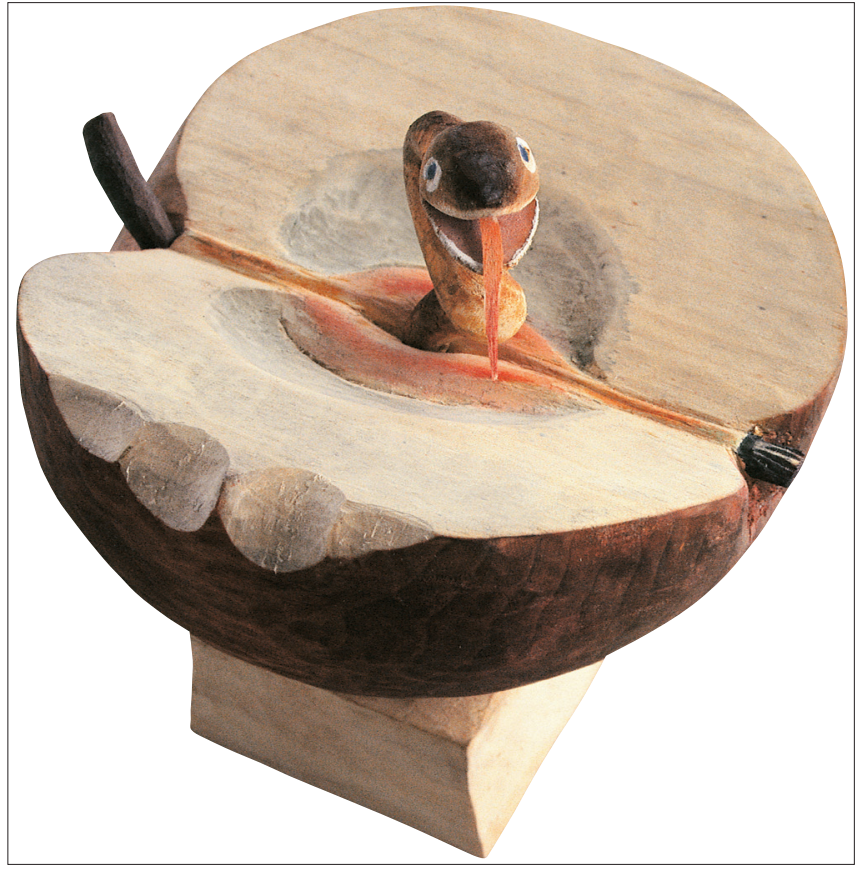

Obr. 6. Adamovo jablko IV, 2004, polychromovaný topol, výška $15 \mathrm{~cm}$. Foto: Jitka Havlová.

Adam's Apple IV, 2004, polychromatic poplar, height $15 \mathrm{~cm}$. Der Adamsapfel IV, 2004, Pappel polychromiert, Höhe $15 \mathrm{~cm}$.

řítku vesnických chalup zasazených i tísněných mezi masivy okolních kopců. Práce z roku 1973 ještě připomínají skladební postupy cyklu italských měst, v roce 1974 a později se však stále více prosazuje motiv krajiny, sochařsky transponovaný bud' do vertikálního, svisle zbrázděného bloku nebo horizontálně prohnutých útvarů, které jako kolébka chovají v sobě lidská obydlí. Hluboké vrstevnicové plastické zvrásnění těchto objektů je nejvýraznější v esovitě prohnuté protáhlé plastice završené motivem samoty - osamělého stavení, známého i z dalších děl. Téma samoty je vyjádřeno i v podobě vertikálně protáhlého kompaktního kubusu s dvojím mělkým vyhloubením nebo vysokého, směrem vzhůru zeštíhleného, prohnutého, vrásněného pilíre s drobnou pyramidou střechy na vrcholu. V Křížovicích Macháček postupně vybudoval svůj ateliér, sochařský amfiteátr a podílí se na činnosti Galerie $\mathrm{z}$ ruky, kterou $\mathrm{v}$ roce 1992 založila a vede sochařova žena Stanislava Macháčková. Galerie představuje tvorbu výtvarných umělců z celé České republiky i ze zahraničí a stala se významnou součástí kulturního života nejen tohoto regionu. Souběžně s komorní plastikou a s tvorbou zásadního významu vytváŕí od poloviny sedmdesátých let i série vtipných dřevěných, nejčastěji zviřrecích plastik pro dětská hřiště: v Kř́žzovicích (1975-1976), v Blansku (1976), v Praze-Kunraticích (1986) a jinde. Jejich forma je většinou dána minimálně přizpůsobeným tvarem dřevěného špalku doplněného kusy štíhlejších kmenů tak, aby vynikla zamýšlená zvířecí podoba. Př́rodní formy jsou co nejvíce zachovány, ale jejich povrch je oživen dekorativními vrypy a řezbami a místy i barvou. Po dílech, $\mathrm{v}$ nichž byl zřetelný důraz na pevnou výstavbu krajiny a v nichž se svým způsobem odrážel její geologický 


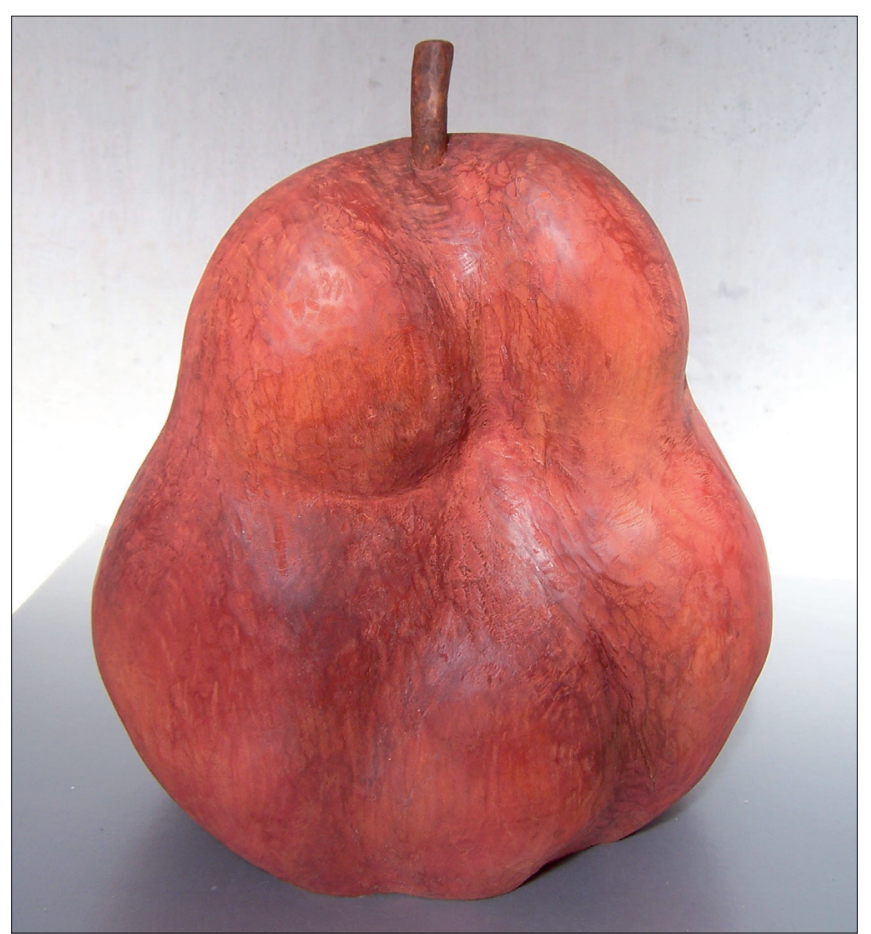

Obr. 7. Erotická hruška, 2006, mořená lípa, výška 25 cm. Foto: Jeannetta Bonefeldová.

Erotic Pear, 2006, stained linden, height $25 \mathrm{~cm}$.

Erotische Birne, 2006, Linde gebeizt, Höhe $25 \mathrm{~cm}$.

i terénní ráz, nastupují od konce sedmdesátých let práce, jejichž charakter je určován pohybem. Vznikají cykly Krajiny strmé a Rozevláté krajiny, plastiky vertikálních, šroubovitě vinutých, vzhůru směřujících forem, u nichž se nabízí paralela $\mathrm{s}$ točícími se cestami vedoucími k vrcholům prríkrých kopců. Prohnutí a pohyb, tak výrazně charakterizující krajinnou sérii, v níž jsou vystupňovány $k$ dynamickému vyznění, se alespoň v náznaku promítají i do námětu figurálního. Tato tvorba nese rys nového pojetí, jež vychází ze základu vertikálního dřevěného bloku a má formu mírně esovitě prohnutého torza. Obdobně jako neobvyklé uchopení námětu italských měst je i Macháčkův přistup k tématu krajiny zcela osobitý. Přitom autor nijak neulpívá na formách, jež se mu již osvědčily, což dokládá i přechod od původně statických prací cyklu Kř́ižovice k Strmým a Rozevlátým krajinám, popírajícím mnohé vžité př̀edstavy o povaze sochařského díla i o ztvárnění tématu jako takového. Také další motivická oblast, která má v tvorbě Zdeňka Macháčka povahu zásadního významu, je těsně spjata s okolní prrírodou. Již ne krajina, ale její součást a zároveň symbol i znak - k obloze se pnoucí kmeny stromů - zaujaly jeho představivost. Vznosné, štíhlé pně lesních stromů ozvučené větrem, který rozevlál Macháčkovy Větrné krajiny, připomínají mohutné píštaly, jejichž výraz sochař citlivě vnímal a ztvárnil podle svých představ. Do kmenů, které po vydlabání pozbyly svou těžkou hmotnost, umístil v různých výškách otvory, jež doplňovaly hlavní, vertikální otevření sloupového tvaru. V nové podobě si tu zopakoval princip hmotného obalu kolem prázdného jádra, kterého před léty úspěšně využil v křrehkých formách Světů ticha. Podobně jako v předchozích

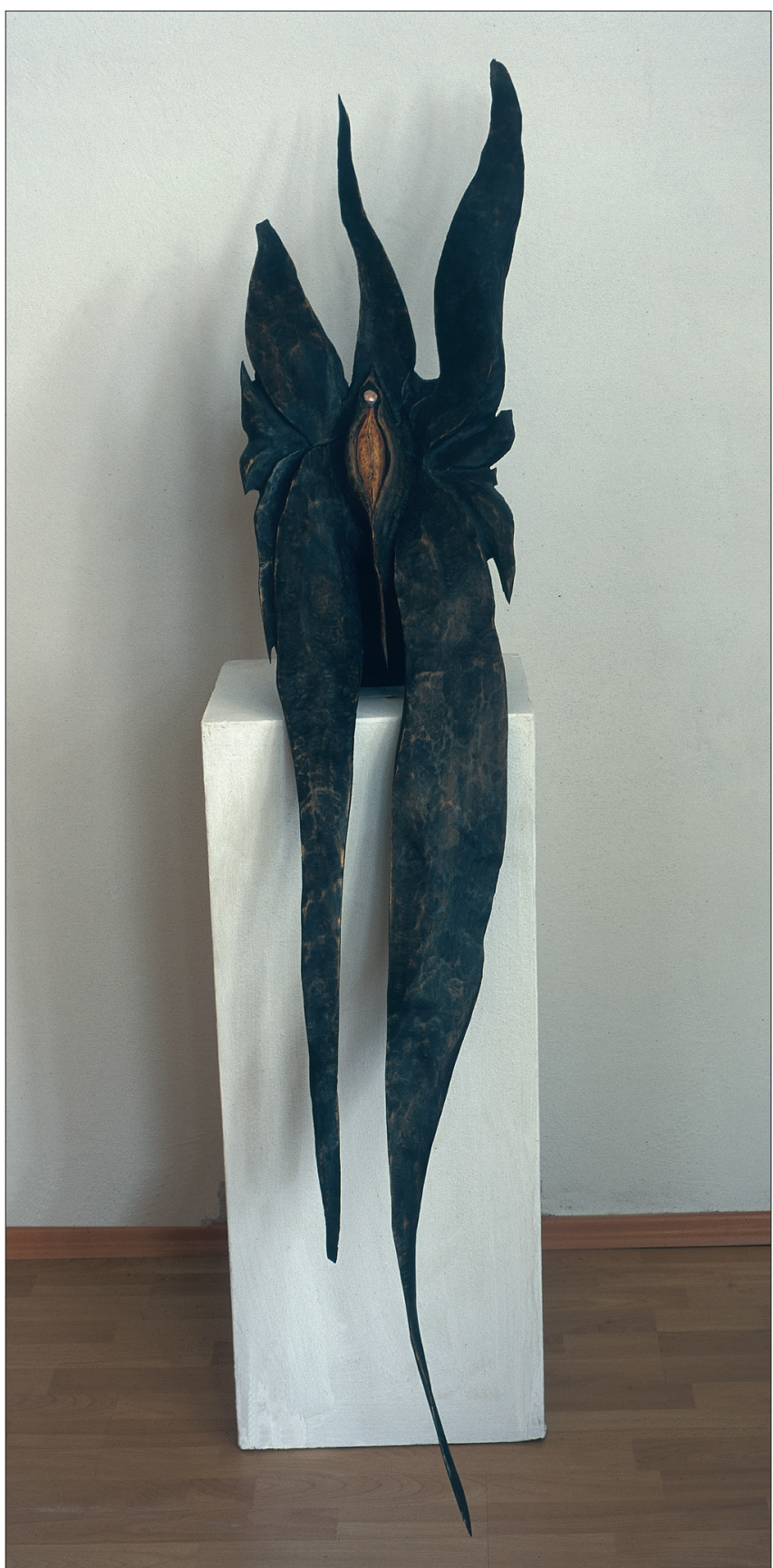

Obr. 8. Perla II, 1999, polychromovaný topol, délka $200 \mathrm{~cm}$. Foto: Vladimír Kosek.

A Pearl II, 1999, polychromatic poplar, length $200 \mathrm{~cm}$.

Die Perle II, 1999, Pappel polychromiert, Länge $200 \mathrm{~cm}$.

tvưrčích etapách, i nyní tvoří Macháčkovy práce námětové cykly, jejichž názvy vyjadřují hlavní téma a odrážejí i poetický rys umělcova vnímání. Nejen představa obrovských prrírodních píštal, ale i asociace s vypjatou vertikalitou gotických chrámových prostor vedla pak Zdeňka Macháčka při utváření objektů, jež nazývá Lesní katedrály. Jejich výška často vícekrát přesahuje lidské měřítko a do jejich stěn - obvodního dřevěného plátu - jsou kromě bočních otvorů jako oken vkomponovány i skleněné výplně - vitráže -, které obraz katedrál dotvářejí. 


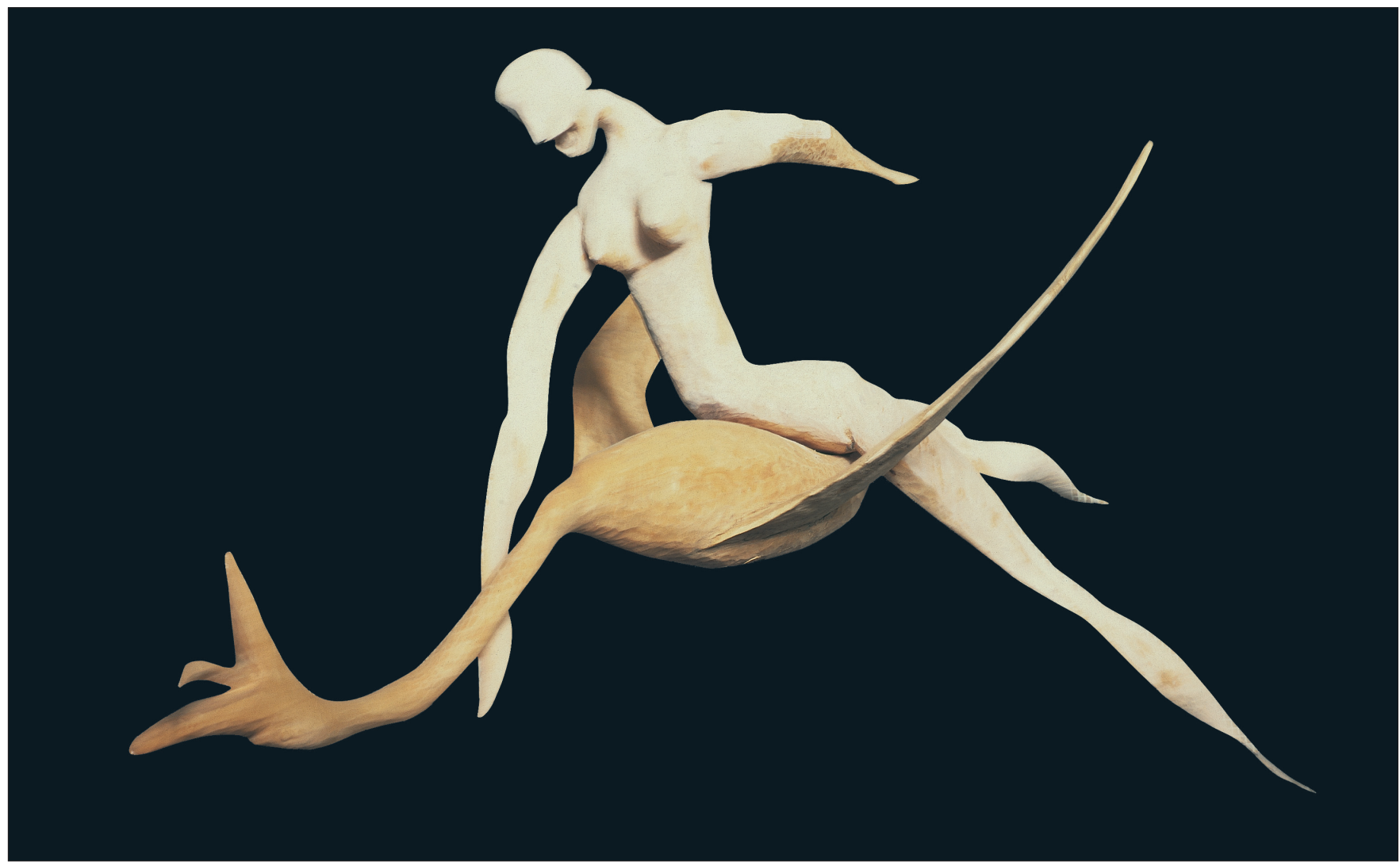

Obr. 9. Léda s labutí, 1998, vrba (Léda), topol (labut'), délka $210 \mathrm{~cm}$. Foto: Vladimír Kosek.

Leda with a Swan, 1998, willow (Leda), poplar (swan), length $210 \mathrm{~cm}$.

Leda mit dem Schwan, 1998, Weide (Leda), Pappel (Schwan), Länge $210 \mathrm{~cm}$.

Motiv vysokých lesních velikánů není v osmdesátých letech jediným autorovým tematickým okruhem. Jeho výrazným protipólem jsou Ulity. Po létech se tu opět setkáváme s kontrapunktem vertikál a kulovitých tvarů, naznačeným již $\mathrm{v}$ dřívější tvorbě a tentokrát vystupňovaným ve dvou samostatných sférách, $\mathrm{z}$ nichž každá svým způsobem navazuje na starší práce. Ulity mohou připomenout formy někdejších Světů ticha, třebaže jsou založeny na plném objemu, narušeném pouze zející puklinou. Hlubší smysl, který autor těmto ladným formám připisuje a jejž zdůrazňuje i v názvu Naše ulity, odpovídá častému životnímu pocitu jedince do sebe uzavřeného a uvězněného ve své osamělosti.

Ve Zpustošených krajinách a Umučených stromech se odehrála proměna pohledu na dřevo - předtím kompaktní, pevnou hmotu, nyní polorozpadlé nebo zprohýbané a rozlámané. A nastoupila i další, zásadní proměna: hmota dřeva jako by byla zbavena tíže a zemské přitažlivosti. Ústředním tématem se opět stává lidská postava, ale $\mathrm{v}$ nové, postupně stále více dematerializované podobě, která již nijak nebrání v letu (Let nad krajinou, 1992, Přelet, 1994, Závrat' letu, 1994, Blaženýlet, 1997, Dovádějící Pegas s múzou, 1997 aj.).

Extáze i poezie letu a touhy mají u Zdeňka Macháčka svůj protipól v dílech naplněných poezií jiného druhu, ve výtvorech budících úsměv a v lecčems blízkých lidovému pojetí. Od počátku devadesátých let vytváří originální dřevěné kašny - nádoby, na jejichž tvaru i vnějším dekoru využil svých zku- šeností a nápadů $\mathrm{z}$ práce na sériích váz pro brněnské výstaviště či obalů na koše pro jihlavské parkány. $Z$ jejich nitra se noří okrouhlá hlava svérázného chrliče. Podobného rodu jsou i Vykukové - blízcí příbuzní chrličů, kteří ovšem místo z vody vykukují za trámy. Kolem roku 1995 zaujala autora představa okřídleného anděla, kterou ztvárnil v řadě figur, jež se vznášejí nebo jen zlehka se dotýkají země. Jejich něžná a zároveň lehce karikovaná podoba se vyznačuje křehkými údy, protáhlým, do řízy zahaleným trupem a paprsčitě rozježenými vlasy. Figurální díla představují bytosti téměř odhmotněné a netělesné, ne však bezpohlavní. Kromě jasných rozlišovacích znaků - vlasů a ňader u ženských aktů, pohlavních údů u aktů mužských - jsou nadány i výraznou schopností vyjádřit erotickou touhu velmi blízkou té, kterou vycitujeme ze Závrati letů, Přeletů nad krajinou i Vyjížděk s koněm a dalších. Ostatně i jejich hry lásky se nejednou odehrávají na hřbetu koně. Podobně jako u dvojic na koňském hřbetu je také téma milenců v sérii Ach ta láska nebeská naplněno vzrušeným pohybem, postavy se k sobě vinou v různě vypjatých pozicích. Ve své extázi se milenci vznášejí v prostoru, at již je sousoší podepřeno vysokou tyčí nebo zavěšeno. Pozornost, kterou Zdeněk Macháček této námětové sféře věnuje, byla $\mathrm{z}$ velké části vyvolána $\mathrm{v}$ polovině devadesátých let výzvou profesora Masarykovy univerzity v Brně Jaroslava Maliny k výtvarné účasti na projektu Kruh prstenu: Světové dějiny sexuality, erotiky a lásky od počátkư do současnosti v reálném životě, krásné 
literatuře, výtvarném umění a dílech českých malírù a sochařu inspirovaných obsahem této knihy. Cílem rozsáhlého projektu je vytvoření knih a výstav na téma „Láska v životě a literatuře světa srdcem a rukama českých malíruo a sochařư “. Zdeněk Macháček v letech 1996-2008 pro tento projekt vytvořil několik desítek plastik a trojrozměrný emblém Kruh prstenu a toto téma neopustil ani po svých osmdesátinách v roce 2005.

Macháčkova tendence $\mathrm{k}$ vystupňovaně štíhlému tvaru je v odlišné podobě zřejmá z plastik Poselství z kosmu (1990) a zvláště pak Růst (1990), v jejichž abstraktní formě opět ožívají inspirace prŕrodními jevy a silami, jež se v různých obměnách v Macháčkově díle vždy znovu a znovu vracejí. Zvláštní podobu nabývají v sérii objektů z cyklu Zpustošená krajina (1991). Jednotlivé části cyklu představují nepravidelné kusy dřev, vybraných pro svůj výrazný tvar, částečně rozpadlých a narušených. Jejich devastaci podpořil autor i zásahem kyseliny sírové, a tím dosáhl účinného mementa, stejně jako v obdobném Poločasu rozpadu (1991). Odlišným způsobem vyjádřil autor svou ideu v plastikách Umučený strom (1992), evokujících představu krucifixu, a Umučené stromy (1992) - skladbě holých štíhlých torz kmenů bez kůry, končících trčícími pahýly. Proměna uskutečněná $\mathrm{v}$ cyklech Zpustošené krajiny a Umučené stromy naučila Macháčkovy postavy létat. Na počátku devadesátých let měli jeho létavci hmotnější objem. Ve druhé polovině devadesátých let jsou neseni křehkýma a často země se nedotýkajícíma nohama a nabiti pohybem. K letu jsou uzpůsobeny i figury již zcela odpoutané od své nositelky krajiny - a nespočívající ani na hřbetu koně. Jen s nepatrným ukotvením proplouvají vzduchem, horizontála jejich trupu i údo̊ je mírně prohnuta a hlava mírí vzhůru. Někdy skupina postav tvoří sousoší pnoucí se od země vzhưru.

V pozdější době sochařovu představivost znovu ovládla krajina. Po více než dvaceti letech nachází nový výraz pro motiv, který pronikl nejen do jeho umění, ale i do jeho života a významně jej ovlivňuje. Bezprostředně po období, jež bylo ve znamení křehce působících vznášejících se postav ztělesňujících nenaplněné lidské touhy, se obrací k hmotným, pevně uchopitelným ztvárněním jednoho ze svých nejvlastnějších námětů - krajiny. Krajiny z roku 2003 a novější jsou proti trojrozměrným Strmým či Větrným krajinám roku 1980 většinou plošší. Vycházejí z tvaru nepř́lišs silného dřevěného plátu, jehož formování někdy jen mírně naznačuje plasticitu v podobě mělkých vypouklin. Macháčkova umělecká tvorba z posledních let by mohla předznamenávat další rozvíjení tématu krajiny a erotiky, které zřejmě nikdy nepřestalo autora poutat. Může však také vyústit do sfér velmi odlišných, jen vzdáleně na ni navazujících. Mohla by být vystřídána vykročením na zcela novou cestu, tak jak tomu bylo u Zdeňka Macháčka již vícekrát...

Zdeněk Macháček uspořádal více než čtyřicet samostatných výstav a zúčastnil se kolem šedesáti výstav kolektivních doma i v zahraničí: Biel (Švýcarsko), Blansko, Boskovice, Brno, Bystřice nad Pernštejnem, Hörle (Švédsko), Kř́ížovice, Perugia (Itálie), Praha, Sharjah (Spojené arabské emiráty), Vídeň (Rakousko), Ždár nad Sázavou aj.

Dílo Zdeňka Macháčka je zastoupeno v galeriích a muzeích u nás i v zahraničí a jeho plastiky stojí na mnoha místech České republiky, na Slovensku a ve Švédsku a jsou součástí desítek architektonických interiérů.

Život a dílo Zdeňka Macháčka jsou podrobně popsány v monografii:

Dvořáková, Nina - Malina, Jaroslav, Zdeněk Macháček. Brno: Akademické nakladatelství CERM, 2005.

\section{LITERATURA}

Dvořáková, Nina - Malina, Jaroslav (2005): Zdeněk Macháček. Brno: Akademické nakladatelství CERM.

Malina, Jaroslav a kolektiv (2007): Kruh prstenu: Světové dějiny sexuality, erotiky a lásky od počátkư do současnosti v reálném životě, krásné literatuře, výtvarném umění a dílech českých malíruo a sochařu inspirovaných obsahem této knihy, 1. „Celý svět" kromě euroamerické civilizace. Brno: Akademické nakladatelství CERM.

Malina, Jaroslav a kolektiv (2009): Antropologický slovník aneb co by mohl o člověku vědět každý člověk ( $s$ přihlédnutím $k$ dějinám literatury a uměni). Brno: Akademické nakladatelství CERM.

Malina, Jaroslav - Zvěřina, Jaroslav (2008): Erotikon sochaře Zdeňka Macháčka. Brno: Akademické nakladatelství CERM.

\section{AUTOR}

Malina, Jaroslav (11. 4. 1945, Dolní Bučice u Čáslavi), český sociokulturní antropolog, archeolog a spisovatel; profesor antropologie na Ústavu antropologie Př́rodovědecké fakulty Masarykovy univerzity; viz: http://anthrop.sci.muni.cz/page.yhtml?id=468.

Kontakt: Prof. PhDr. Jaroslav Malina, DrSc., Ústav antropologie Př́rodovědecké fakulty Masarykovy univerzity, Vinařská 5, 60300 Brno, e-mail: jmalina@sci.muni.cz. 


\title{
THE PROJECT THE CIRCLE OF THE RING OR ANTHROPOLOGY OF SEXUALITY: ZDENĚK MACHÁČEK
}

\author{
JAROSLAV MALINA
}

The Project The Circle of the Ring: The World History of Sexuality, Eroticism and Love from the Beginnings up to the Present Day in Real Life, Belle-Lettres, Visual Art and in the Works of Czech Painters and Sculptors Inspired by the Content of this Book arose at the beginning of the 1990s. It presents the formation of the representative publication in three volumes and a collection of erotica of Czech painters and sculptors. The publication consists of the following three volumes:

The Circle of the Ring, 1: "The Whole World" except the Euro-American Civilisation (2007);

The Circle of the Ring, 2: The Euro-American Civilisation (2013);

The Circle of the Ring, 3: The Czech World (2015).

The mentioned publication in three volumes presents the treatise of the development of human sexuality, eroticism, love and marriage in biological, general anthropological and cultural and historical contexts together with the presentation of the most interesting works of literature and fine art of the past and the reproductions of the pictures and sculptures made by about seventy Czech painters and sculptors inspired by the content of the single volumes at the end of the 20 th and at the beginning of the $21^{\text {st }}$ centuries.

The author of the subject matter and of the whole project is Jaroslav Malina, co-authors of the whole publication in three volumes are Marie Dohnalová, Jan Filipský, Helena Honcoopová, Blahoslav Hruška, Josef Kandert, Oldřich Kašpar, Josef Kolmaš, Miroslav Králík, Adéla Křikavová, Olga Lomová, Miriam Löwensteinová, Klára Macúchová, Giuseppe Maiello, Jakub Maršálek, Jaroslav Oliverius, Lucie Olivová, Alena Opletalová, Marie Pardyová, Jiří Pavelka, Lydia Petráňová, Ivo Pospíšil, Jaroslav Skupnik, Jiří A. Svoboda, Miloš Štědroň, Hana Třísková, Břetislav Vachala, Václav Vančata, Marina Vančatová, František Vrhel and Jaroslav Zvěřina, i. e. specialists in American studies, anthropologists, arabists, archaeologists, egyptologists, ethnologists, historians, experts in Indian, Japanese and Korean studies, literary historians, sexologists, sinologists, specialists in Sumerian and Tibetan studies and other experts who - thanks to their erudition - show the reader round history, culture and ethics of the relations between man and woman of "their world" and select literary and visual illustrations so that - regardless of the necessary limited number and range - the specific features of single cultural and historical areas of our planet in their evolution from primeval age and antiquity up to the modern times became most apparent.

A holistic work has evolved - one that seems to be unique.

Particular volumes of the journal Anthropologia integra will include short profiles on the participating artists as well as reproductions of some of their artefacts created for the project The Circle of the Ring.

Today: sculptor Zdeněk Macháček (designer of the sculptural emblem of The Circle of the Ring; his latest work is the sculptural emblem for The Encyclopaedia of Anthropology).

\section{ZDENĚK MACHÁČEK}

Human sexuality, erotica and love pervade the entire sculptural oeuvre of Zdeněk Macháček, evolving throughout the almost 60 year long artistic career in harmony with the development and transformations of his creative language and mounting life experience. His affinity to this theme became even more intensive when in 1996 he was invited to participate in the artistic aspects of a project involving a three-volume publication and exhibitions: The Circle of the Ring: The World History of Sexuality, Eroticism and Love from the Beginnings up to the Present Day in Real Life, Belle-Lettres, Visual Art and in the Works of Czech Painters and Sculptors Inspired by the Content of this Book (Jaroslav Malina and co-authors). Macháček's oeuvre for this project is exceptional. It has become evident that the given theme is very close to his heart - in fact, maybe the closest - because from 1997-2008 he not only created dozens of sculptures for this project (including the three-dimensional emblem for The Circle of the Ring), but he also wrote some unusually humorous and linguistically refined commentaries as an accompaniment to several of the sculptures. It is evident that he is capable of shaping and forming words and the Czech language in particular in such a masterful way and with the same kind of love that he devotes to the raw materials for his sculptures.

Zdeněk Macháček was born on 16 August 1925 in Brno.
After finishing grammar school he studied zoology and anthropology at the Faculty of Science of Masaryk University in Brno in 1945-1947. After three years of study he was forced to leave university for "staffing (ideological or class) reasons" (his family owned a graphics enterprise) and for the same reason he was also rejected at the College of Arts and Crafts in Prague. In 1952 he finished his studies at the School of Arts and Crafts in Brno, after which he was employed for a short time; since 1961 he has been living as a freelance artist. At first he worked in Brno, but in 1971 he left for Kř́žovice near Doubravník where he has been living and working until now. In 1958 he became one of the founding members of the artistic group Parabole; he has been a member of the Brno creative Association Q and the Horácko (hilly region in western Moravia) Club of Artists. He co-founded the international symposium of sculptors The Wooden Sculpture in Ždár nad Sázavou and became its main organiser.

In the mid-1950s Zdeněk Macháček entered the world of Czech art, although at first only the narrow circle within the Brno art community, as a sculptor whose fate it was to primarily work with wood. In the artefacts going back to the end of the 1950s and to the beginning of the 1960s, his main work included a series of intimate antique finish wood-carvings with animal themes. Among the most characteristic is the repeating bull motif whose constricted, rounded form contains an element of hidden force and dynamism. The simplified 


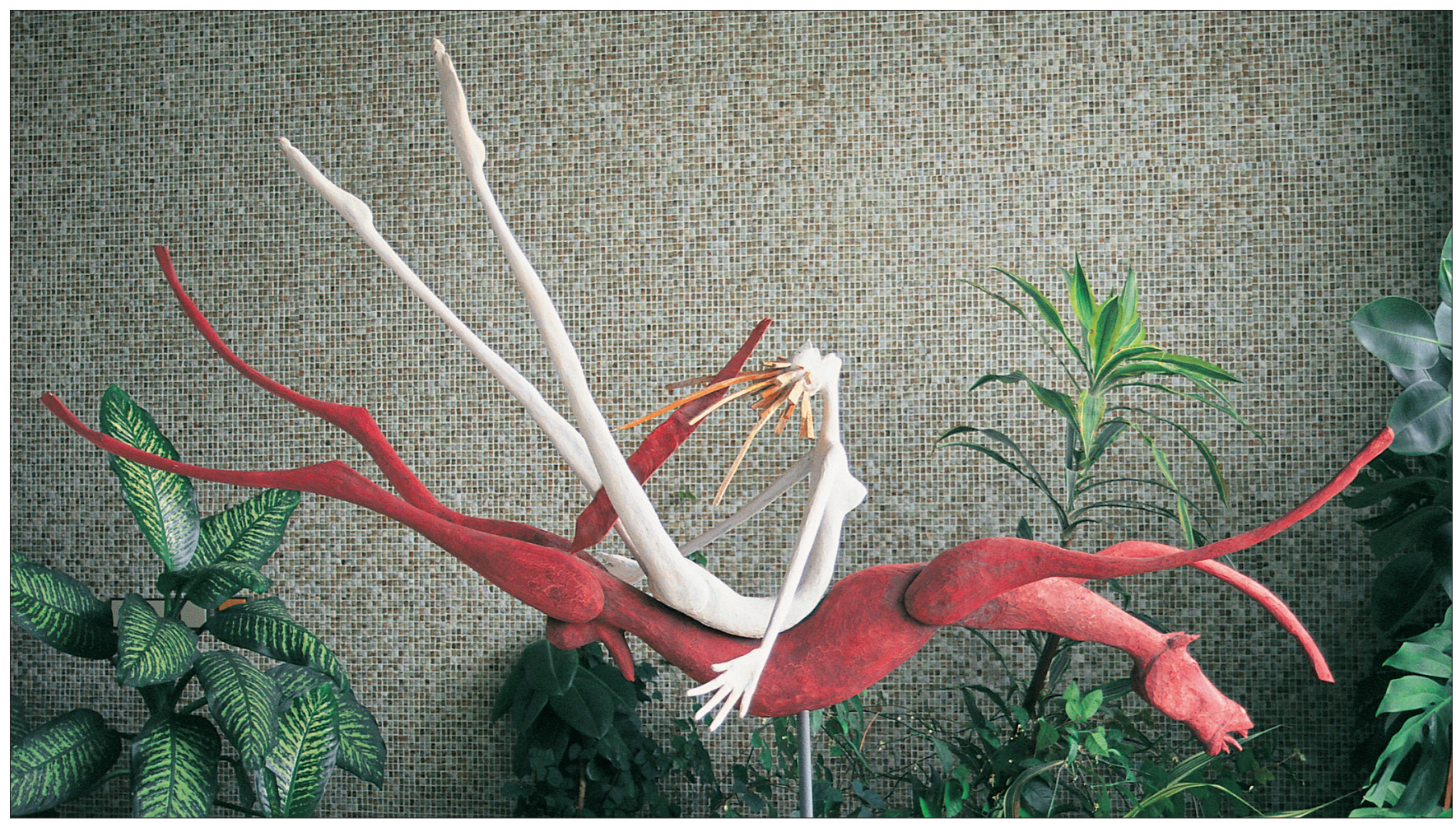

Obr. 10. Múza na červeném koni, 2004, polychromované dřevo, délka 200 cm. Foto: Jitka Havlová.

A Muse on the Red Horse, 2004, polychromatic wood, length $200 \mathrm{~cm}$.

Muse auf einem roten Pferd, 2004, Holz polychromiert, Länge $200 \mathrm{~cm}$.

form omits descriptive details and in spite of the rather small dimensions, it reveals a sense of monumentality. However, this is a creation of indisputable artistic value which becomes even more apparent when it is compared with the larger part of the usual Czech artistic production of the 1950s. It contains, above all, some principles or indications of the features which would characterise the sculptor's work in various periods.

At the beginning of the 1960s there is a significant turn: the series of animal sculptures, generally of small dimensions, is substituted by a cycle of female figures - Venuses - and the change of theme brings about a modification of the sculptor's expression which goes far beyond the outer identity with objective reality. In the new formation of the figure and the female torsos, the artist's lively sense of form and capacity continue to be intensified and are later used again when returning to this timeless subject. He gradually developed an autonomous form only remotely reminiscent of a figure: stylised, fully plastic figures form a certain shell around an inner kernel, or a slim trunk with a bosom surrounded by a case with a hollowed inner space. This principle of the selection of the form and the formation of a case around an empty space are among the most significant features of Macháček's artistic style - in various periods and in different forms. That is the beginning of the first artefacts for public areas which would become a very important part of Macháček's work. In the 1960s his important works include Sculptures of Animals (1961, Anthropos Pavilion of the Moravian Regional Mu- seum in Brno-Pisárky), Birds (1966, Brno Exhibition Centre in Brno-Pisárky), Nature and Man (1968, Institute for Further Education of the Secondary School Health Care Workers in Brno-Pisárky [now The National Centre for Health Care and Non-Health Service Disciplines]), just to name a few.

During the 1960s the series of Venuses was substituted, or more specifically was concurrently accompanied, by a series of different artefacts called Worlds of Silence. Its rise was due to a discovery for which the author is very grateful - the specific environment under water that he intimately knew being a diver. The Worlds of Silence represent a new quality in the artist's creation.

The principle modification is not only the shift from the figurative subject towards the new motifs formed in an abstract way and drawn from nature, but new sculpting approaches as well. The idea became an outer case around a hollowed kernel. Bizarre, slender, elongated forms contrast against the globular, gyroidally curled ones. The outer case could also be a closed little cage with holes through which we can penetrate into the interior where another plastic form is hidden. The impression of the fragile shells arises, partly evoked by the very reduced capacity of a wooden casing which hides and at the same time reveals the inner space of the sculpture. The external outline of single forms is gently continuous as if smoothed by the sea. In The Worlds of Silence Macháček's work of the early 1960s culminates. His relation to nature finds a very personal expression here and his sense of woodcarving reaches its virtuosity, though he does not abandon the characteristic features 


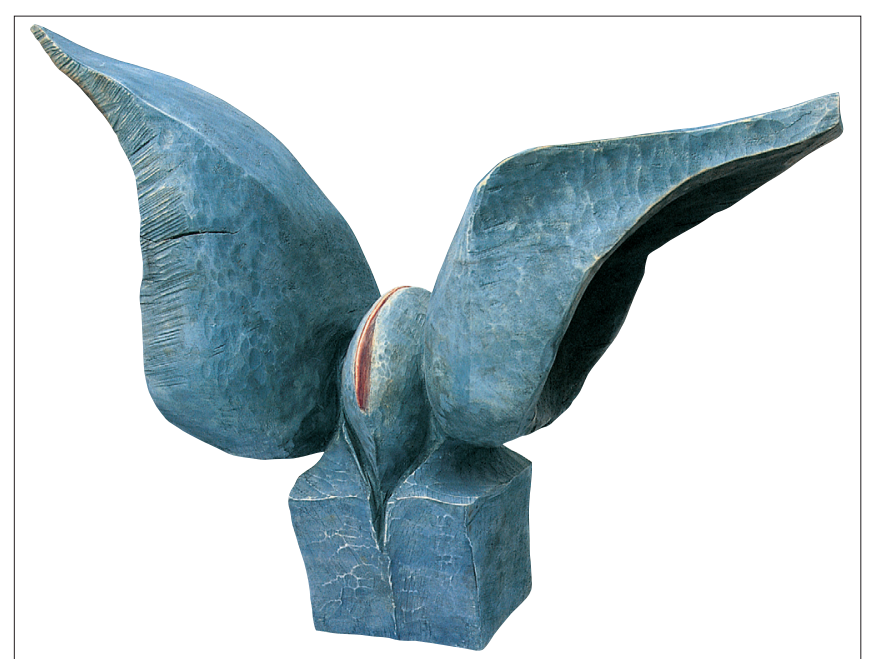

Obr. 11. Létající erotický objekt, 2004, mořený topol, výška $62 \mathrm{~cm}$. Foto: Jitka Havlová.

A Flying Erotic Object, 2004, stained poplar, height $62 \mathrm{~cm}$

Fliegendes erotisches Objekt, 2004, Pappel gebeizt, Höhe $62 \mathrm{~cm}$.

of the material. Even after The Worlds of Silence, Macháček continues to be attracted by the world of nature. Unlike their fragile, aesthetically elaborated and dematerialised abstraction, the new motifs have a tersely cut, material capacity. The persuasive expression of the artist's relation to the thematic sphere he was closely interested in was the triple grouping $\mathrm{Na}$ ture and Man (1968), installed in Brno-Pisárky (the grounds of the Institute for Further Education of the Secondary School Health Care Workers in Brno-Pisárky [now The National Centre for Health Care and Non-Health Service Disciplines]). The two column objects are reminiscent of totems and have a richly structured surface. There is significant contrast represented in the low globular sculpture which is hollow inside and manifesting a heart with stylised arteries. This first of his outdoor works made of wood is exceptional both in its nondescriptive communication of a given idea and its impressive choice of the material composition - high verticals and a low globular form, whose artistic effect the sculptor verified in his Worlds of Silence. Both the stately columns are in fact the beginning of a long series of trunks of forest trees formed in a sculptural way representing one of the most significant stages of his artistic development.

In 1964-1969 he would go on study trips to Italy every year. The profound experience of the Italian landscape and its historical cities led to the cycle of specific objects Italian Cities consisting of the firm kernel surrounded by compound crystals of cubic forms. Without any indication of personification or symbols, there is a sculptural expression of the artist's perception of the character of the cities, their disposition and location in the landscape. For the expression of these impressions, feelings and perceptions, the author developed his own form-setting morphology which is common for the whole cycle of Italian Cities, but at the same time reflects the differences of various localities. In principle, they are big, irregularly rendered blocks contrasting with the minor forms. The artistic idea developed in the cycle of Italian Cities was also

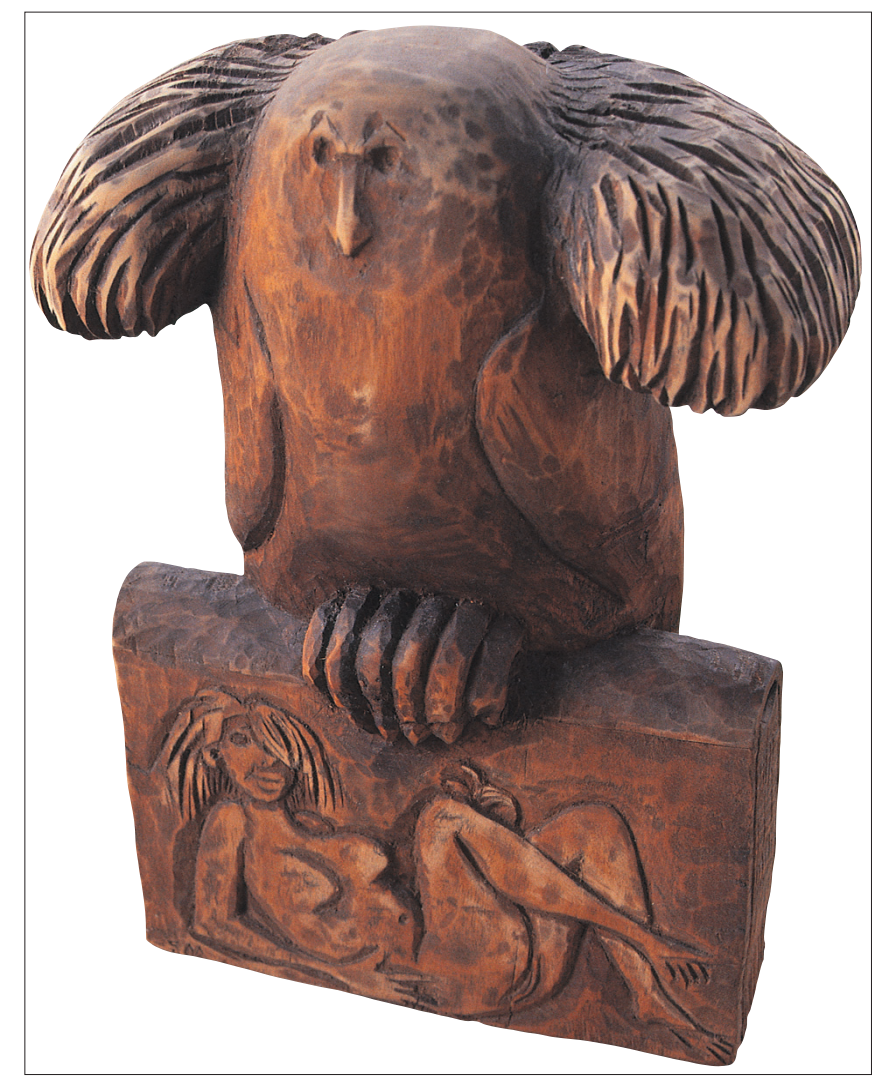

Obr. 12. Sova erotoman, 2003, mořený topol, výška $20 \mathrm{~cm}$. Foto: Jitka Havlová. The Owl-Erotomaniac, 2003, stained poplar, height $20 \mathrm{~cm}$. Eule - die Erotomane, 2003, Pappel gebeizt, Höhe $20 \mathrm{~cm}$.

applied in a new form in the new creative phase of his life, the setting of which was simply the little village of Kř́žovice.

In 1971 he moved to Kř́žovice near Doubravník where he has been living up to now. This year represents a turning point in the artist's life and work. The location of Krrížovice in the hilly countryside at the foothills of the Czech-Moravian Highlands far from main roads is both a new impulse and the confirmation of his preceding artistic starting points. The nature which surrounds him becomes a permanent part of his life and work. Similarly, as he formed his specific impression of the Italian Cities, in which he applied his sense of the monumental disposition of matter, in the cycle Krížovice he becomes attached to the minor dimensions of village cottages set and enclosed among the massifs of the neighbouring hills. The artefacts going back to 1973 still remind one of the structural approaches of Italian Cities; in 1974 and later, however, he increasingly applies the motif of the landscape transposed sculpturally either into the vertically furrowed block or horizontally bent forms which in a cradle-like fashion contain the human dwellings. The deep, contoured plastic wrinkling of these objects is most expressive in the sigmoidally bent elongated sculpture culminated by the motif of loneliness - the lonely dwelling being well-known from his other works. The theme of loneliness is expressed in the form of a vertically elongated compact cube with a double shallow hollow, or by a high pillar, slenderized upwards, bent, wrinkled, and with tiny pyramidal roofs on the top. In Křížovice he gradually constructed his studio and the 


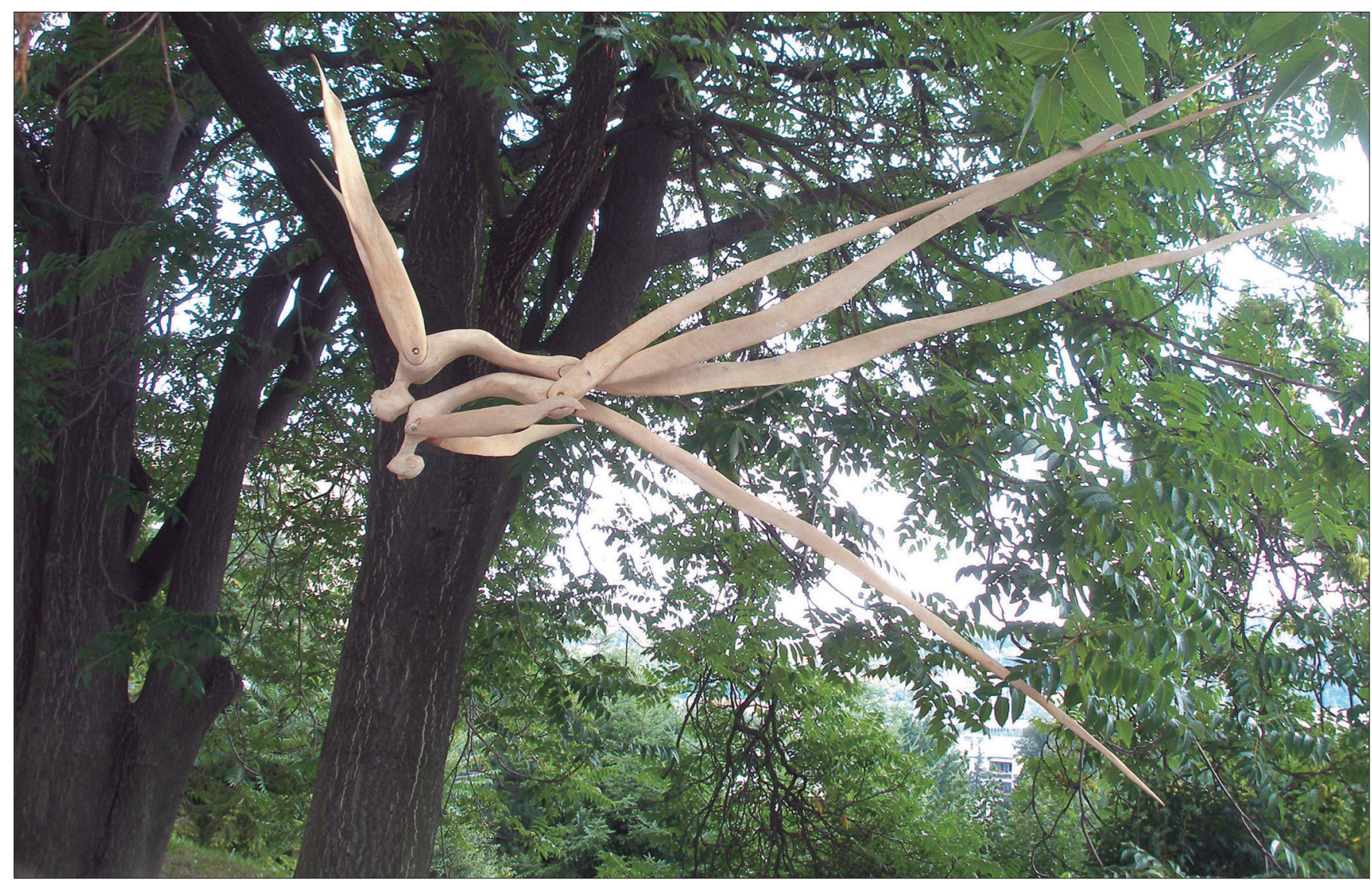

Obr. 13. Láska je vzlétat ... II, 1999, červená vrba, délka $300 \mathrm{~cm}$. Foto: Vladimír Kosek.

Love is to Float ... II, 1999, red willow, length $300 \mathrm{~cm}$.

Liebe heißt Auffliegen ... II, 1999, rote Weide, Länge $300 \mathrm{~cm}$.

sculptor's amphitheatre; he also participated in the activity of the Out of Hand Gallery, which was founded in 1992 and run by his wife Stanislava Macháčková. The gallery has been presenting the work of artists both from the whole Czech Republic and abroad, becoming a significant part of the cultural life of not only this region.

Along with the intimate sculptures and with the work of fundamental importance since the mid-1970s, he also created a series of witty wooden, most often animal sculptures for children's playgrounds: in Kř́žovice (1975-1976), Blansko (1976), Prague-Kunratice (1986) and other places. Their form can generally be defined by the modestly adapted shape of the wooden chopping block completed with pieces of slimmer trunks so that the intended animal shape becomes apparent. The natural forms are preserved as much as possible, but their surfaces are enhanced with decorative scratches, cuts and colour in some places.

After the artefacts in which the dominant emphasis is linked with the disposition of landscape reflecting its geological character and terrain, since the end of the 1970s he has been creating works characterised by their use of motion. That is the time when the cycles The Steep Landscapes and The Exuberant Landscapes appear: sculptures of vertical, spiral-like forms going upwards, representing a parallel with winding paths leading to the tops of steep hills. The bending and mo- tion so clearly characterising the landscape series in which they are intensified to a dynamic finish are also projected in the figural subject - at least by indication. It contains the feature of a new conception based on the vertical wooden block and has the form of a slightly sigmoidally bent torso. Similar to his extraordinary grasp of the subject of Italian cities, Macháček's approach is also very specific. At the same time, he does not cling to the forms which had already proved themselves; that can be manifested in the transition from the originally static works of the cycle Krížovice to The Steep and Exuberant Landscapes, negating many of the common concepts of the nature of the sculptor's work and of the formation of the subject as such. Another sphere of motifs which is fundamental in Zdeněk Macháček's work is closely connected with the surrounding nature. No longer just landscape, but its parts and at the same time its symbols and signs attracted his imagination - tree trunks rising to the sky. The stately, slim trunks of forest trees with the sound of wind which wave in Macháček's Windy Landscapes remind one of mighty pipes, the expression of which the sculptor perceived sensitively and formed from his visions. After hollowing out the trunks so that they lose their heaviness, he placed openings inside in different positions; this completed the main, vertical opening of the column form. In the new form he repeated this principle of a material casing around an empty kernel, successfully ap- 


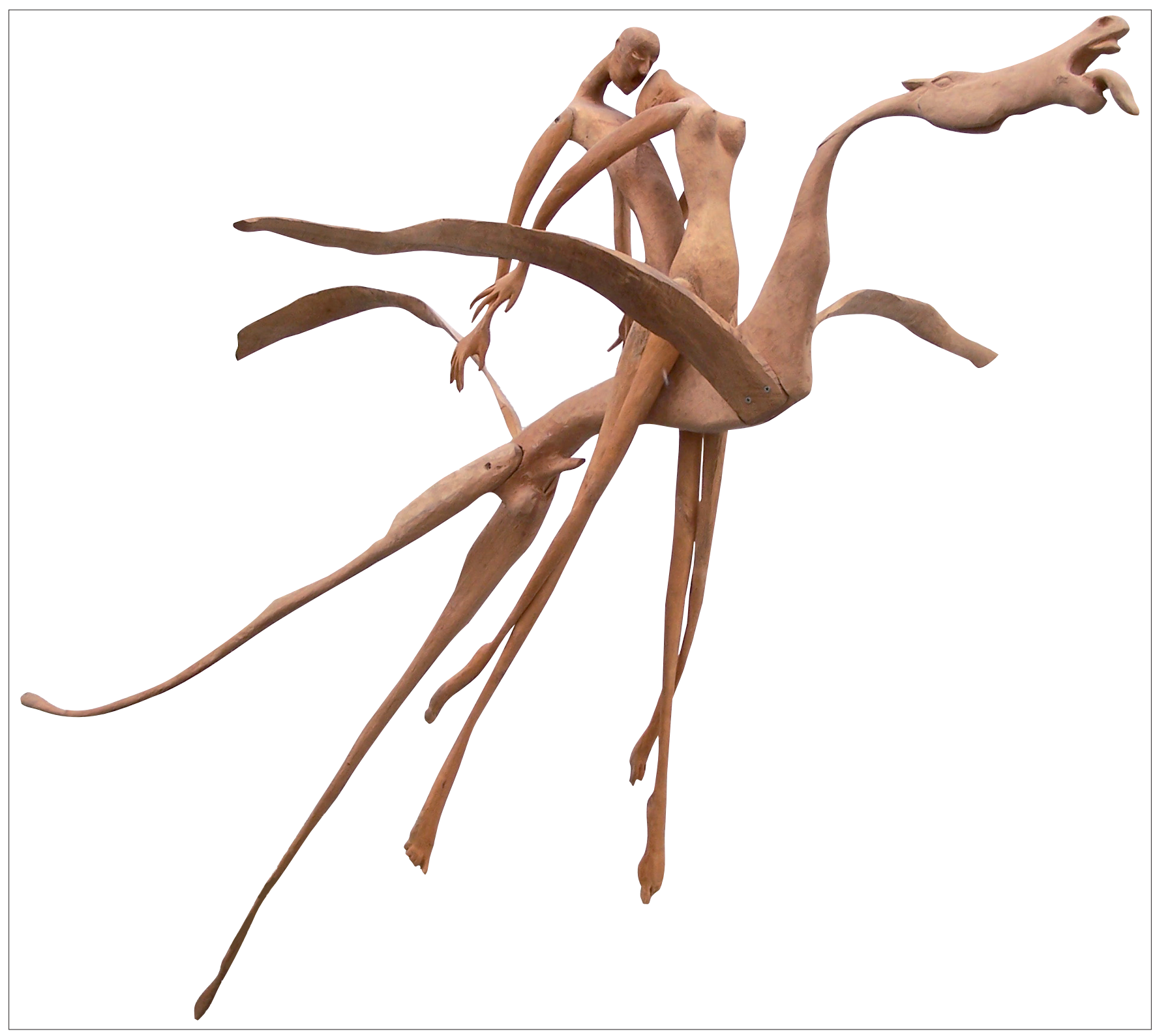

Obr. 14. Dva na koni II, 1999, topol, délka $188 \mathrm{~cm}$, šírka $168 \mathrm{~cm}$. Foto: Jeannetta Bonefeldová.

Two on the Horseback II, 1999, poplar, length $188 \mathrm{~cm}$, width $168 \mathrm{~cm}$.

Zwei auf dem Pferd II, 1999, Pappel, Länge $188 \mathrm{~cm}$, Breite $168 \mathrm{~cm}$.

plying the fragile forms of The Worlds of Silence. Like in his preceding creative stages, Macháček's works form the thematic cycles whose titles express the main subject and also reflect the poetic feature of the artist's perception. Not only the vision of huge natural pipes, but also the association with the verticality of a gothic cathedral space led him in the process of constructing objects called The Forest Cathedrals. Their height surpasses normal human scale many times over. Elements are set into their walls completing the image of a cathedral: a peripheral wooden plate, side openings as windows, glass fittings and antique glass panes.

The motif of high forest tree giants is not the only theme of the artist. Its striking antipode is Shells. After many years there is again the counterpoint of verticals and globular forms already indicated in his earlier work and this time intensified in the two independent spheres, each continuing his older work in its own way. The shells may be reminiscent of the forms of the former World of Silence, although they are based on a full capacity corrupted only by a gaping split. A deeper sense which the author ascribes to these elegant forms and which he also stresses in the title Our Shells corresponds to the life-long feeling of an individual locked in his own self and imprisoned in his loneliness.

In Devastated Landscapes and Tortured Trees such modifications in his view on wood also take place: what earlier was compact firm matter now is half-disintegrated, bent and broken. A new fundamental change appeared: as if the material of the wood had lost its heaviness and gravitation. The 
central theme is the human figure again, but in a new, gradually more dematerialised shape, which is not prevented from flying any more (The Flight over the Landscape, 1992; The Passage, 1994; The Vertigo of the Flight, 1994; The Blissful Flight, 1997; The Pegasus Cavorting with the Muse, 1997; and others). The ecstasy and poetry of flight and desire in Macháček's work have their antipode in those works filled with a poetry of another kind: in creations evoking a smile and similar to a folk conception to a certain extent. Since the 1990s he has been creating original wooden fountains - containers in form and decorated using his experience and ideas from work on a series of vases for the Brno Fair Grounds, or basket casings for strengthened fortifications in Jihlava. From its interior, the round head of a peculiar gargoyle appears. The same kind is also Sprucers - closely related to gargoyles, but peeping from behind timbers rather than from the water. Around 1995 the artist was attracted by the vision of a winged angel who he formed in a series of figures that float or just lightly touch the earth. Their tender and slightly caricatured face is characterised by fragile limbs, an elongated trunk veiled in a gown and by radially ruffed hair. The figural artefacts depict the beings as nearly dematerialised and non-physical, but not asexual. Besides the clear differentiating indicators - hair and bosom in female nudes, penises in male nudes - they are also endowed with the distinct ability to express erotic desire that is very close to that which can be felt from Vertigo of Flights, The Passage over the Landscape, The Horse Ride and others. All the same, even their love games take place on horseback. As with the couples on horseback, the theme of lovers in the series $\mathrm{Oh}$, This Heavenly Love, which is filled with excited movement, the figures get together in different tense positions. In their ecstasies the lovers float in space no matter if the sculptural group is supported or hung. The attention that the artist pays to this thematic cluster inspired Professor Jaroslav Malina of Masaryk University Brno in the mid-1990s, when he invited Macháček to artistically participate in the project The Circle of the Ring: The World History of Sexuality, Eroticism and Love from the Beginnings up to the Present Day in Real Life, Belle-Lettres, Visual Art and in the Works of Czech Painters and Sculptors Inspired by the Content of this Book. The aim of this huge project is the creation of books and exhibitions related to the subject "Love in the Life and Literature of the World through the Heart and Hands of Czech Painters and Sculptors". From 1996-2008 Zdeněk Macháček created dozens of sculptures for this project as well as a three-dimensional emblem for The Circle of the Ring. Even after his 80th birthday in 2005, it seems that he has not abandoned these themes.

Macháček's tendency towards an escalated slim form is evident in a different form through his sculptures A Message from the Cosmos (1990) and especially The Growth (1990). Their abstract forms, inspired by natural phenomena and forces, revive and reappear in various modifications of Macháček's work. They assume a specific form in the series of objects from the cycle The Devastated Landscape (1991). The separate parts of the cycle are represented by irregular pieces of wood that are selected for their expressive form - partly disintegrated and disrupted. Their devastation was enhanced by the artist with the use of sulphuric acid; this led to an expressive memento, as in The Half-Life (1991). In a different way the artist expressed his idea in the sculptures A Tortured Tree (1992), evoking a vision of the cross, and Tortured Trees (1992), a composition of slim bare trunk torsos - protruding stumps without bark.

In the cycles The Devastated Landscapes and Tortured Trees a change in his view of wood takes place: originally compact, firm matter - now half-disintegrated, or distorted and broken. Then another change followed: it was as if the wood material found itself without weight and gravitation. The central subject is the human figure again, but in a new, gradually more dematerialised form which in no way prevents it from flying. At the beginning of the 1990s Macháček's fliers are carried by fragile figures and often they do not touch the earth with their feet, but are charged with motion. The figures become completely unbound from their bearer - the landscape - and become adapted to flying; they no longer even sit on horseback. They fly through the air only slightly fastened, the horizontality of their trunks and limbs is only slightly bent and their heads move upwards. Sometimes a group of figures forms a sculptural group going upwards from the earth.

Recently the sculptor's imagination was subjugated by the landscape again. After more than 20 years, he finds new expression for the motif which penetrates not only his art, but also his life, strongly influencing it. Right after the period which was characterised by the fragile floating figures embodying unfulfilled human desires, he turns to material, firmly palpable objects of one of his most intrinsic subjects - the landscape. From 2003 the landscapes are unlike the three-dimensional Steep or Windy Landscapes of 1980, but somewhat flatter. They are based on the shape of a not too thick wooden plate, whose formation only slightly indicates its plasticity in the form of shallow bulges. Macháček's artistic work of recent years could anticipate further development of the theme of landscape and eroticism, which, as it seems, did not cease to appeal to him. It can, however, flow into very different spheres which are only remotely similar. It could also mean setting out on quite a new journey, as it was several times in the past in the work of the artist.

Zdeněk Macháček has organised more than 40 individual exhibitions and participated in about 60 group exhibitions in this country and abroad: Biel (Switzerland), Blansko, Boskovice, Brno, Bystřice nad Pernštejnem, Hörle (Sweden), Kř́žovice, Peruggia (Italy), Prague, Sharjah (United Arab Emirates), Vienna (Austria), and Ždár nad Sázavou. His work is exhibited in numerous galleries and museums: the sculptures stand in many locations in the Czech Republic, Slovakia, and Sweden and form an interesting part of dozens of architectonic interiors.

The life and work of Zdeněk Macháček are described in more detail in the following monograph: Dvořáková, Nina - Malina, Jaroslav, Zdeněk Macháček. Brno: Akademické nakladatelství CERM, 2005. (Translation by Šárka Roušavá) 


\title{
PROJEKT DER KREIS DES FINGERRINGES ODER ANTHROPOLOGIE DER SEXUALITÄT: ZDENĚK MACHÁČEK
}

\author{
JAROSLAV MALINA
}

Mit dem Projekt Der Kreis des Fingerringes: Weltgeschichte der Sexualität, Erotik und Liebe von den Anfängen bis zur Gegenwart - dargestellt im realen Leben, in der Belletristik, der Bildenden Kunst und in Kunstwerken vom Inhalt des vorliegendes Buches inspirierter tschechischer Maler und Bildhauer, das Anfang der neunziger Jahre des vorigen Jahrhunderts entstand, wurde eine repräsentative dreibändige Publikation samt einer Sammlung von Erotika tschechischer Maler und Bildhauer gestaltet.

Die genannte Trilogie besteht aus folgenden Bänden:

Der Kreis des Fingerringes, 1 „Die ganze Welt" außer der euroamerikanischen Zivilisation (2007);

Der Kreis des Fingerringes, 2 Euroamerikanische Zivilisation (2013);

Der Kreis des Fingerringes, 3 Tschechische Welt (2015).

In der Trilogie wird die Entwicklung der menschlichen Sexualität, Erotik, Liebe und der Ehe im Rahmen biologischer, allgemein anthropologischer und kulturell-historischer Zusammenhänge behandelt und gemeinsam mit interessantesten literarischen und künstlerischen Werken der Vergangenheit sowie Reproduktionen von zeitgenössischen Gemälden, Zeichnungen und Plastiken präsentiert, die gegen Ende des 20. und Anfang des 21. Jahrhunderts von rund sieben Dutzenden vom Inhalt einzelner Bände inspirierter tschechischer Maler und Bildhauer geschaffen wurden.

Der Autor der Konzeption und des gesamten Projekts ist Jaroslav Malina, die Mitverfasser sind Marie Dohnalová, Jan Filipský, Helena Honcoopová, Blahoslav Hruška, Josef Kandert, Oldřich Kašpar, Josef Kolmaš, Miroslav Králík, Adéla Kř̌ikavová, Olga Lomová, Miriam Löwensteinová, Klára Macúchová, Giuseppe Maiello, Jakub Maršálek, Jaroslav Oliverius, Lucie Olivová, Alena Opletalová, Marie Pardyová, Jiří Pavelka, Lydia Petráňová, Ivo Pospíšil, Jaroslav Skupnik, Jiř́ A. Svoboda, Miloš Štědroň, Hana Tř́sková, Břetislav Vachala, Václav Vančata, Marina Vančatová, František Vrhel und Jaroslav Zvěřina, das heißt Amerikanisten, Anthropologen, Arabisten, Archäologen, Ägyptologen, Ethnologen, Historiker, Indologen, Japanologen, Koreanisten, Literaturhistoriker, Sexuologen, Sinologen, Sumerologen, Tibetologen und weitere Spezialisten, die dank ihrer Erudition den Leser durch Geschichte, Kultur und Ethik der Beziehungen zwischen Mann und Frau innerhalb „ihrer“ Welt führend begleiten, wobei sie die literarischen und künstlerischen Beispiele so geeignet wählen, dass die Spezifika einzelner kulturhistorischer Gebiete unseres Planeten in ihrer Entwicklung seit den Urzeiten bis in die moderne Zeit trotz einer notwendigen Limitierung in Anzahl und Umfang der vorgestellten Werke deutlich werden.

Hiermit ist ein einheitliches und allem Anschein nach auch einzigartiges Werk entstanden.

In den einzelnen Heften der Zeitschrift Anthropologia integra werden die Porträts der am genannten Projekt beteiligten Künstler veröffentlicht und einige für Den Kreis des Fingerringes geschaffene Artefakte wiedergegeben.

Heute: Der Bildhauer Zdeněk Macháček (Autor des plastischen Emblems für das Projekt Der Kreis des Fingerringes; sein jüngstes Werk ist das plastische Emblem für die Enzyklopädie von Anthropologie).

\section{ZDENĚK MACHÁČEK}

Die menschliche Sexualität, Erotik und Liebe durchdringen das ganze Bildhauerwerk von Zdeněk Macháček. Das Thema wandelte sich im Verlauf seiner fast sechzigjährigen schöpferischen Laufbahn in Übereinstimmung mit der Entwicklung und den Veränderungen seiner künstlerischen Sprache und zunehmenden Lebenserfahrungen. Seine Zuwendung dem genannten Thema vertiefte sich noch, als er 1996 zur Teilnahme an einem auf ein dreibändiges Buch und eine Ausstellung gerichteten Projekt herausgefordert wurde: Der Kreis des Fingerringes: Weltgeschichte der Sexualität, Erotik und Liebe in den Weltkulturen von den Anfängen bis zur Gegenwart - dargestell tim realen Leben, in der Belletristik, der bildenden Kunst und in Kunstwerken vom Inhalt des vorliegenden Buches inspirierter tschechischer Maler und Bildhauer (Jaroslav Malina und Kollektiv).

Macháčeks Werk für dieses Projekt ist von außerordentlichem Wert. Es hat sich herausgestellt, dass das festgelegte Thema ihm sehr gut, sogar bestens vertraut ist, denn in den Jahren 1996-2008 schuf er für das Projekt nicht nur Dutzende von Plastiken (einschließlich eines dreidimensionalen Emblems Der Kreis des Fingerringes), sondern verfasste zu einigen da- von witzige und sprachlich geschliffene Kommentare. Es ist offenbar, dass der Künstler die tschechische Sprache ebenso meisterhaft und mit Liebe bearbeiten kann wie seinen bildhauerischen Werkstoff.

Zdeněk Macháček wurde am 16. August 1925 in Brünn geboren. Nach Abschluss des Realgymnasiums studierte er Zoologie und Anthropologie an der Naturwissenschaftlichen Fakultät der Masaryk-Universität in Brünn. Nach drei Jahren musste er „aus Kadergründen“ diese Schule verlassen (seine Familie war im Besitz eines graphischen Betriebes); aus demselben Grund wurde er an der Hochschule für Kunstgewerbe in Prag nicht angenommen. 1952 absolvierte er die Höhere Schule für Kunstbewerbe in Brünn. Nach seinem Studienabschluss war er kurzzeitig angestellt, seit 1961 ist er freischaffend. Zunächst wirkte Macháček in Brünn, später (1971) zog er nach Křrižovice, wo er bis heute lebt und schöpferisch tätig ist. 1958 wurde er Gründungsmitglied der Gruppe Parabola (Parabel), jetzt ist er Mitglied der Künstlervereinigung Q in Brünn und des Klubs der Künstler von Horácko (Region in Westmähren). Er hat das Internationale Symposium Holzplastik in Ždár nad Sázavou mitbegründet, zu dessen Hauptveranstalter er wurde.

Seine Laufbahn in der tschechischen bildenden Kunst begann 


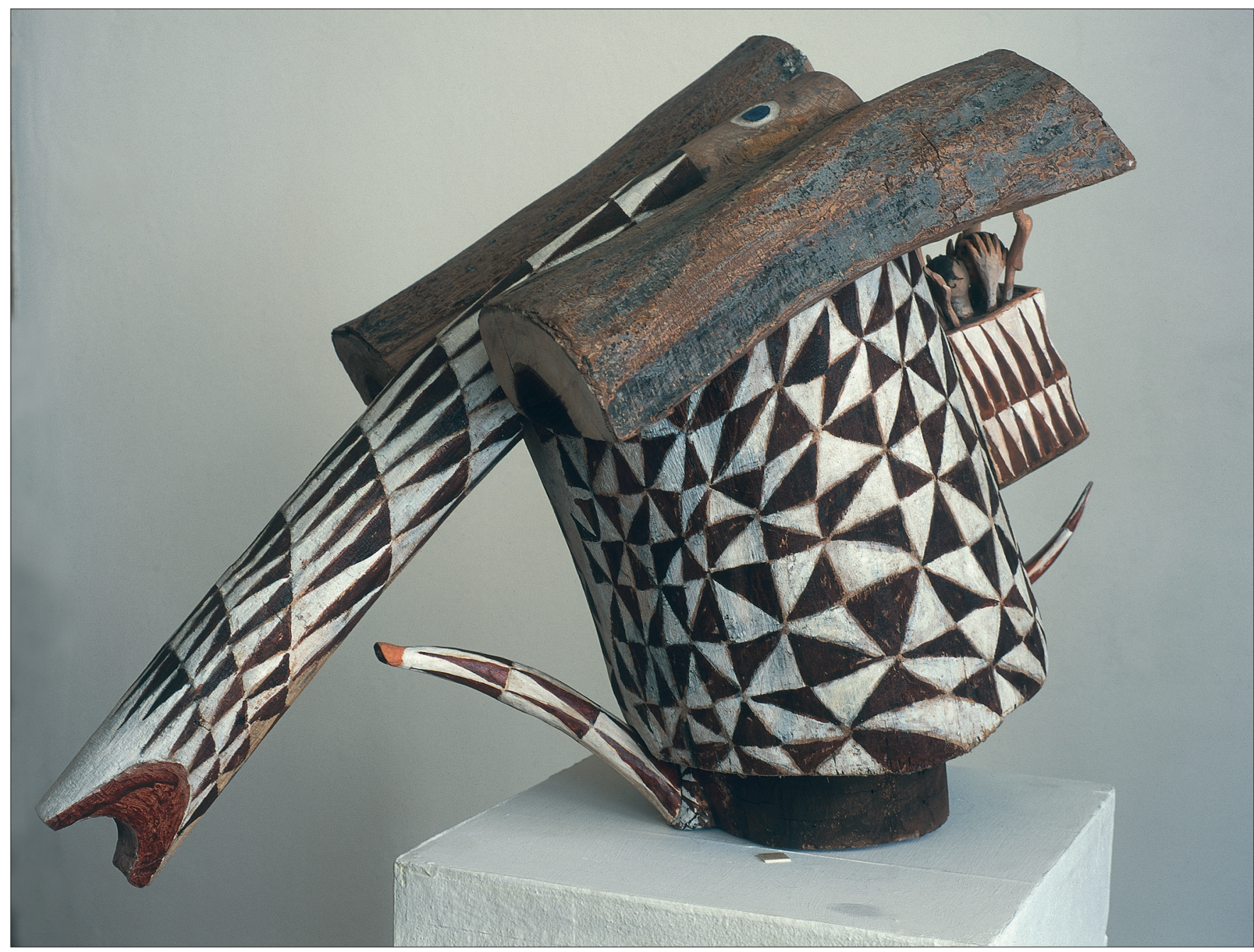

Obr. 15. Milování na slonu, 2000, jilm (slon), červená vrba (dvojice v nosítkách na hřbetě slona), výška $49 \mathrm{~cm}$, šírka $63 \mathrm{~cm}$. Foto: Vladimír Kosek. Making Love on the Elephant, 2000, elm tree (elephant), red willow (a couple in a sedan on the elephant's back), height $49 \mathrm{~cm}$, width $63 \mathrm{~cm}$. Liebespaar auf dem Elefanten, 2000, Rüster (Elefant), rote Weide (Liebespaar in der Trage auf dem Elefantenrücken), Höhe $49 \mathrm{~cm}$, Breite $63 \mathrm{~cm}$.

Mitte der fünfziger Jahre, anfangs jedoch im engen Kreis des Brünner Kulturgeschehens als Bildhauer, in seinem künstlerischen Schicksal vom Material Holz entscheidend bestimmt. Unter Macháčeks Arbeiten vom Ende der fünfziger und Anfang der sechziger Jahre steht an vorderster Stelle eine Serie von patinierten Klein-Holzschnitten mit Tiermotiven. Eines seiner Kennzeichen ist das immer wiederkehrende Stiermotiv, dessen fest geschlossene rundliche Form Elemente von Kraft und Dynamik in sich birgt. Die vereinfachte Form dieser Arbeiten verzichtet auf beschreibende Details und trotz kleiner Maße verrät sie Macháčeks Sinn für Monumentalität. Die erwähnten Werke sind zweifellos von großem künstlerischem Wert, der im Vergleich zum Großteil der in den fünfziger Jahren üblichen Produktionen der tschechischen bildenden Kunst besonders auffällt. Sie beinhalten etliche Prinzipien oder deren Andeutungen, durch die dann auch das reife bildhauerische Werk des Künstlers in verschiedenen Schaffensperioden geprägt ist.

Anfang der sechziger Jahre vollzog sich eine wichtige Wandlung in seinem Schaffen. Eine Reihe von überwiegend kleinen
Tierplastiken wurde durch einen Zyklus von Venus-Figuren abgelöst, wobei sich auch seine künstlerische Ausdrucksweise veränderte: sie entfernte sich immer weiter von der auf äußerliche Merkmale gegründeten Wiedergabe der gesehenen Realität. In der neuen Darstellung von Frauenfiguren und weiblichen Torsos steigerte sich sein Sinn für Form und Umfang, um später in immer neuer Wiederkehr zu diesem ewigen Thema zur Geltung zu kommen. Nach und nach entwickelte er eine autonome Form, die nur entfernt an eine Figur erinnert: stilisierte, ganz plastische Figuren bilden eine Art Schale rund um den Kern darinnen - oder ein schlanker Schaft mit Brüsten ist mit einer von innen ausgehöhlten Hülle ummantelt. Dieses Prinzip, das die Materie abbaut und dadurch eine Hülle rund um leeren Raum entstehen lässt, gehört in verschiedenen Phasen und vielfältigen Gestalten des Werkes Macháčeks zu den charakteristischen Zügen seines künstlerischen Stils. In den sechziger Jahren entstanden auch erste Plastiken für öffentliche Räume, die zu einem gewichtigen Bestandteil seines Schaffens geworden sind. Dazu zählen insbesondere Tierplastiken (1961, Pavillon Anthropos des Mährischen Landesmu- 


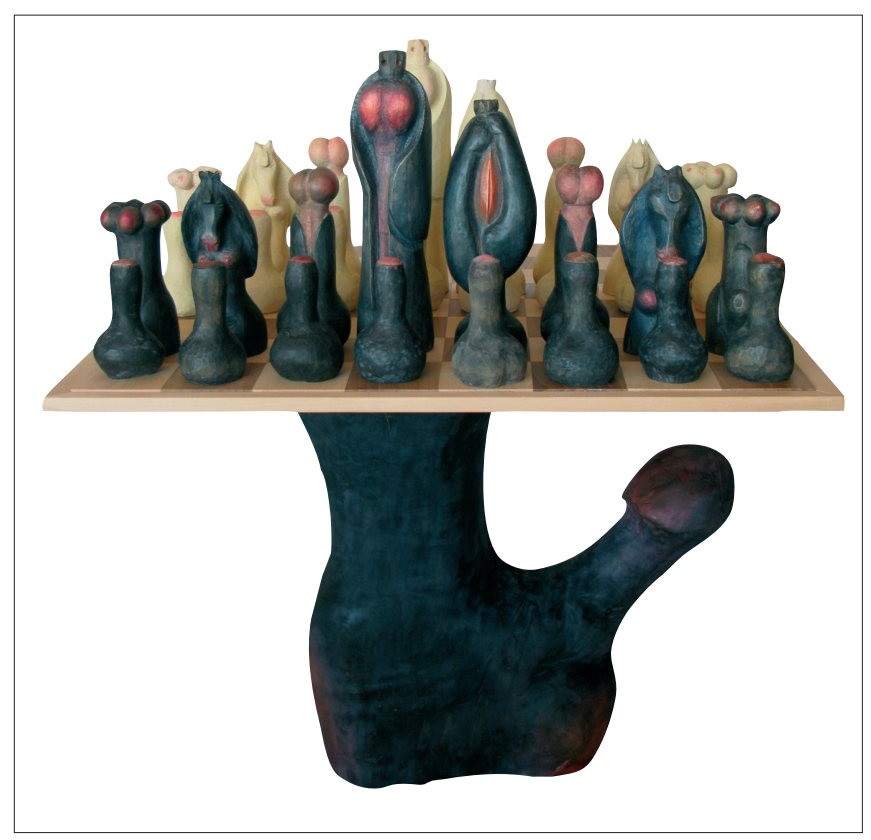

Obr. 16. Erotické šachy s Erotem, 2007-2008, polychromovaný topol (šachy), výška 12,5-33 cm, polychromovaný kaštan (Eros, podstavec I), výška $59 \mathrm{~cm}$. Foto: Tomáš Mořkovský.

Erotic chess with Eros, 2007-2008, polychromatic poplar (chess), height 12.5$33 \mathrm{~cm}$, polychromatic chestnut tree (Eros, pedestal I), height $59 \mathrm{~cm}$. Foto: Tomáš Mořkovský.

Erotisches Schach mit Eros, 2007-2008, Pappel polychromiert (Schach), Höhe $12,5-33 \mathrm{~cm}$, Kastanie polychromiert (Eros, Gestell I), Höhe $59 \mathrm{~cm}$.

seums in Brno-Pisárky), Vögel (1966, Messegelände der Gesellschaft Messe Brünn in Brno-Pisárky), Natur und Mensch (1968, Gelände des Instituts für Weiterbildung für medizinisches Personal in Brno-Pisárky [jetzt Nationales Zentrum für Pflegewesen und nichtärztliche medizinische Bereiche]) u. a. Im Verlauf der sechziger Jahre wurde die Venus-Serie von mehreren ganz unterschiedlichen Arbeiten unter dem Namen Welten der Stille parallel begleitet. Die Idee verdankt der Bildhauer einer Entdeckung der blauen Tiefe, einer besonderen Welt, mit der er sich als Taucher vertraut machte. Die Welten der Stille brachten eine neue Qualität ins Schaffen des Künstlers.

Die entscheidende Veränderung lag nicht nur im Übergang von figuralen Themen zu neuen, aus der Natur schöpfenden, abstrakt dargestellten Motiven, sondern sie kam wiederum auch in einer neuen bildhauerischen Technik zum Ausdruck. Seine Arbeitsmaterie wurde die Hülle, die einen ausgehöhlten Kern umschloss. Bizarre, schlanke, lange vertikale Gebilde stehen im Kontrast zu solchen von kugel- und wendelförmiger Gestalt. Die äußere Schale kann auch als Käfig wahrgenommen werden, durch deren Lücken man in das Innere hineinblicken kann, wo sich ein weiteres Gebilde verbirgt. Auf solche Weise wird der Eindruck von zerbrechlichen Schalen erweckt, wozu ein stellenweise auf ein Minimum verdünnter Holzmantel beiträgt, der den inneren Raum zwar umgibt, zum Teil aber auch enthüllt. Das Oberflächenprofil einzelner Formen ist glatt und kontinuierlich, wie von Meereswellen poliert. In den Welten der Stille gipfelte das Schaffen Machá-

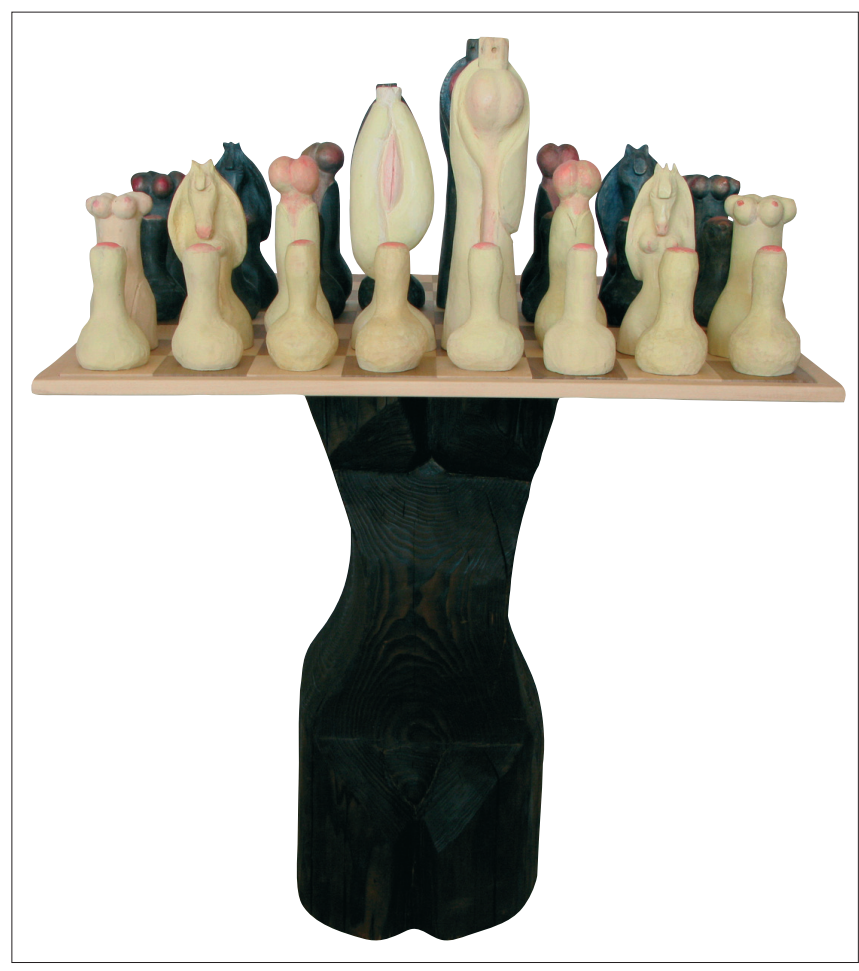

Obr. 17. Erotické šachy s Venuší, 2007-2008, polychromovaný topol (šachy), výška $12,5-33 \mathrm{~cm}$, pálený smrk (Venuše, podstavec II), výška $65 \mathrm{~cm}$. Foto: Tomáš Mořkovský.

Erotic chess with Venus, 2007-2008, polychromatic poplar (chess), height $12.5-33 \mathrm{~cm}$, burned spruce (Venus, pedestal II), height $65 \mathrm{~cm}$.

Erotisches Schach mit Venus, 2007-2008, Pappel polychromiert (Schach), Höhe 12,5-33 cm, Fichte gebrannt (Venus, Gestell II), Höhe $65 \mathrm{~cm}$.

čeks in der ersten Hälfte der sechziger Jahre. Seiner Beziehung zur Natur verlieh er eine individuelle Note, und in der Arbeit mit Holz erreichte er wahre Virtuosität, ohne auf charakteristische Eigenschaften des Materials verzichtet zu haben.

Nach den Welten der Stille wurde der Künstler auch weiterhin von der Natur angezogen. Im Gegenteil zur fragilen, ästhetisch verfeinerten und entmaterialisierten Abstraktion der Welten der Stille wurden neue Motive lapidar in die Holzmasse gehauen. Beredtes Zeugnis vom Vertrauensverhältnis des Künstlers zur Natur und von seinem intensiven Interesse für dazugehörige Themen ist die dreidimensionale Gruppe Natur und Mensch (1968), die in Brno-Pisárky (Gelände des Instituts für Weiterbildung für medizinisches Personal [jetzt Nationales Zentrum für Pflegewesen und nichtärztliche medizinische Bereiche]) aufgestellt wurde. Zwei hohe säulenartige Objekte, die an Totems erinnern, sind auf der ganzen Oberfläche reichlich strukturiert. Im Kontrast zu diesen Säulen steht eine niedrige, kugelförmige, innen ausgehöhlte Plastik, die das Herz mit stilisierten Arterien darstellt. Die erste aus Holz gefertigte Exterieur-Plastik Macháčeks ist außergewöhnlich; sowohl durch die nicht beschreibende Mitteilung ihrer Idee als auch durch eine effektvolle Kombination von hohen Vertikalen und einer kugelartigen Form, deren Wirkung er bereits bei den Welten der Stille ausprobierte. Beide hochstrebenden Säulen stehen eigentlich am Anfang einer langen Reihe von künstlerisch gestalteten Waldbaumstämmen, die eine der be- 


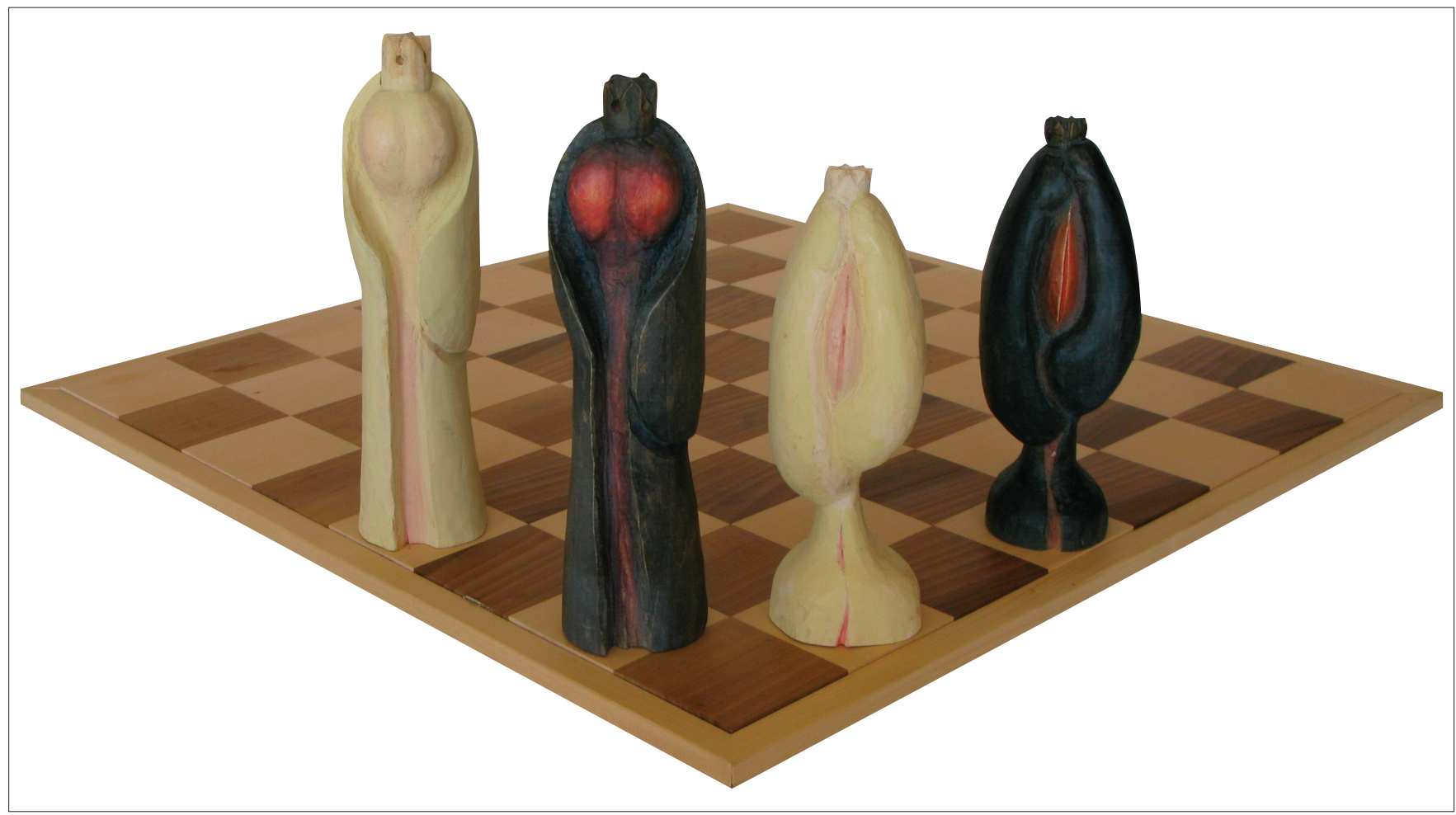

Obr. 18. Král a Dáma, z cyklu Erotické šachy, 2007-2008, polychromovaný topol, výška $33 \mathrm{~cm}, 27,5 \mathrm{~cm}$. Foto: Tomáš Mořkovský.

King and Queen, from the cycle Erotic chess, 2007-2008, polychromatic poplar, height $33 \mathrm{~cm}, 27.5 \mathrm{~cm}$.

König und Dame, vom Zyklus Erotisches Schach, 2007-2008, Pappel polychromiert, Höhe $33 \mathrm{~cm}, 27,5 \mathrm{~cm}$.

deutendsten Schaffensetappen des Bildhauers gefüllt haben. In den Jahren 1964-1969 unternahm Macháček alljährlich Studienreisen nach Italien. Unter dem starken Eindruck italienischer Landschaften sowie historischer Städte entstand der Zyklus Italienische Städte. In ihm entwickelten sich besondere Objekte, die durch einen festen, mit verwachsenen kubischen Formen umgebenen Kern gekennzeichnet sind. Ohne irgendwelche Personifizierung oder Symbole anzudeuten, konnte der Künstler sein Wahrnehmen einzelner Städte - ihre Anordnung, Einbettung in der Landschaft - mit rein bildhauerischen Mitteln zum Ausdruck bringen. Um seine Eindrücke, Gefühle und Erkenntnisse darzustellen, entwickelte der Bildhauer eine eigene, den Zyklus als Gesamtheit prägende Formenlehre, wobei er jedoch Verschiedenheiten der Lokalitäten widerzuspiegeln vermochte. Im Prinzip handelt es sich um große, unregelmäßig bearbeitete Stämme, die mit kleineren Gebilden kontrastieren. Die im Zyklus Italienische Städte entwickelte Idee konnte der Autor in einer anderen Gestalt zur Geltung bringen, und zwar in einer neuen Etappe seines Lebens und Schaffens, zu deren Schauplatz das kleine Dörfchen Kř́źžovice geworden war.

1971 zog er an diesen Ort, wo er bis heute lebt. Dieses Jahr wurde zum Wendepunkt in seinem Leben und Werk. Die Lage des Dorfes im hügeligen Vorgebirgsland abseits der Hauptwege war für ihn ein neuer Arbeitsimpuls, zugleich aber die Bestätigung seiner älteren künstlerischen Ausgangspunkte. Die Natur, die sich hier rings um ihn herum befand, wurde auf Dauer zum Bestandteil seines Lebens. Kurz vor dem Um- zug vermittelte er seine originelle Auffassung der italienischen Städte, in der der Sinn für monumentale Gliederung der Materie hervortrat - nach dem Umzug dann im Zyklus Kř́žovice richtete er sich auf die Miniaturausmaße der in den umliegenden Bergen eingebetteten und auch verklemmten Landhäuser aus. Die Arbeiten von 1973 erinnern noch an die kompositorische Vorgehensweise des Zyklus Italienische Städte, aber im Jahr 1974 und später setzte sich mehr und mehr eine andere Auffassung durch: das Landschaftsmotiv wurde entweder in einen vertikalen, senkrecht durchfurchten Block oder in ein horizontal gebogenes Gebilde übertragen, das die menschlichen Niederlassungen aufbewahrte wie in einer Wiege. Ein tiefes Schichtengefältel dieser Objekte ist in der S-förmig gebogenen, in die Länge gezogenen, mit dem Motiv des Einödhauses gekrönten Plastik am markantesten. Das schon von anderen Werken Macháčeks bekannte Motiv des Einödhauses wird auch in Form eines vertikal verlängerten kompakten Kubus mit doppelter flacher Aushöhlung oder in Form eines hohen, sich aufwärts verjüngenden, gebogenen Pfeilers mit einer kleinen Dachpyramide auf dem Gipfel gestaltet.

In Křížovice baute Macháček Schritt für Schritt seinen Atelier und ein Bildhaueramphitheater aus. Er beteiligt sich nach wie vor an der Tätigkeit der „Galerie Abseits“, die 1992 seine Frau Stanislava Macháčková gegründet hat und bis jetzt leitet. Die Galerie präsentiert Werke der bildenden Künstler aus der Tschechischen Republik sowie aus dem Ausland und ist zum wichtigen Bestandteil des Kulturlebens nicht nur in dieser Region geworden. 


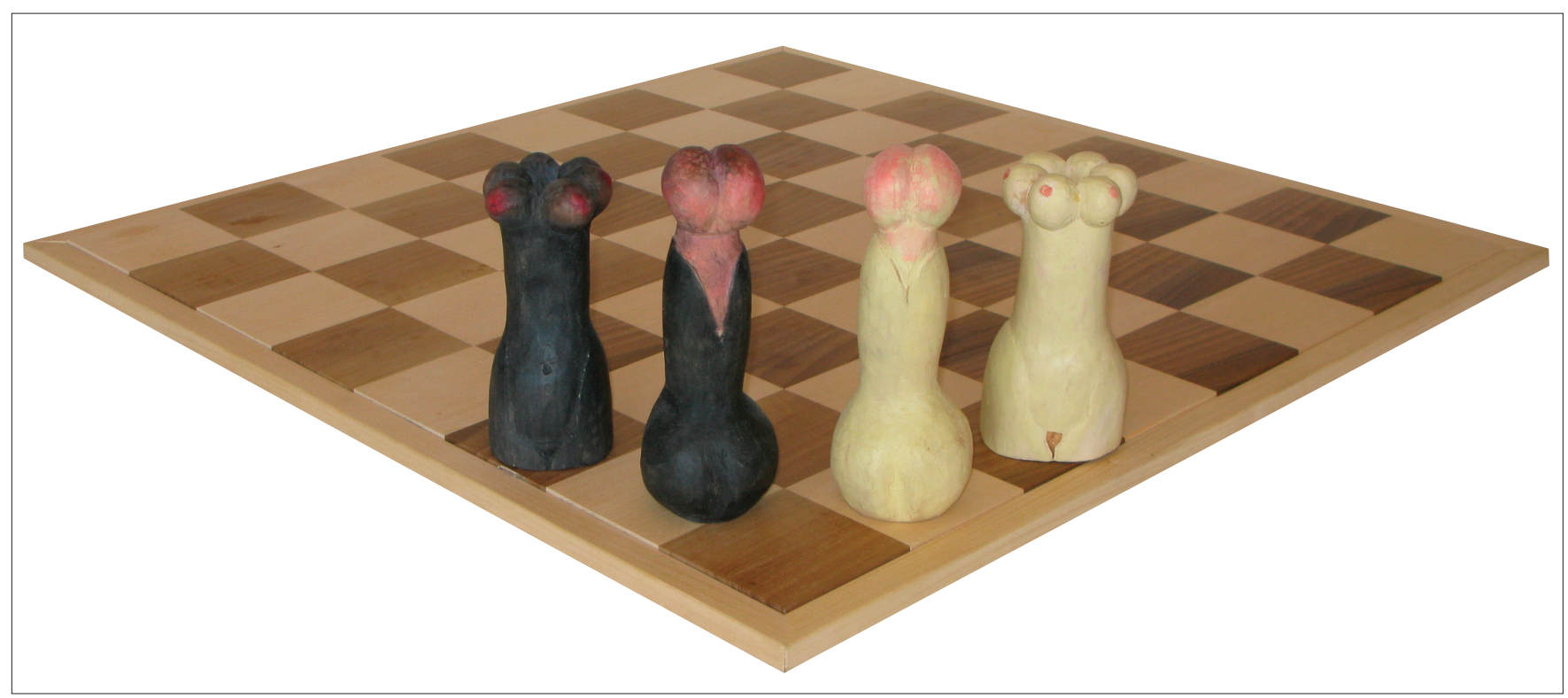

Obr. 19. Střelec a Věž, z cyklu Erotické šachy, 2007-2008, polychromovaný topol, výška 20 cm, $16,5 \mathrm{~cm}$. Foto: Tomáš Mořkovský.

Bishop and Rook, from the cycle Erotic chess, 2007-2008, polychromatic poplar, height $20 \mathrm{~cm}, 16,5 \mathrm{~cm}$.

Läufer und Turm, vom Zyklus Erotisches Schach, 2007-2008, Pappel polychromiert, Höhe $20 \mathrm{~cm}, 16,5 \mathrm{~cm}$.

Parallel mit der Kleinplastik und den Plastiken von grundlegender Bedeutung schuf der Bildhauer seit Mitte der siebziger Jahre auch Serien von witzigen hölzernen Plastiken, meist mit Tiermotiven, für Kinderspielplätze: in Křŕžovice (1975-1976), in Blansko (1976), in Praha-Kunratice (1986) und in anderen Orten. Die Form der Plastiken ist meist durch eine minimal angepasste Form eines Holzblocks gegeben, der mit schmaleren Stämmen so ergänzt wird, dass die gewünschte Tierform deutlich hervortritt. Die Naturformen wurden womöglich erhalten, wobei die Oberfläche mit dekorativen Ritzen, Schnitzarbeiten und stellenweise auch mit Farbe belebt wird.

Den Werken, die die feste Landschaftsstruktur akzentuieren und den geologischen sowie geländeeigenen Charakter widerspiegeln, folgten seit Ende der siebziger Jahre Arbeiten, deren Wesen durch Bewegung geprägt wird. In jener Zeit entstanden die Zyklen Schroffe Landschaften und Flatternde Landschaften - Plastiken in vertikalen, schraubenartigen, emporstrebenden Formen, bei denen sich eine Parallele zu schlängelnden Wegen anbietet, die zu Berggipfeln steil hinaufsteigen. Die für die Serie von Landschaften typischen Elemente wie Biegung und Bewegung, die zu einem dynamischen Ausklang gesteigert werden, spiegeln sich wenigstens andeutungsweise auch in figuralen Themen wider, wo ein vertikaler Holzblock als Grundstock und die Gestalt eines S-förmigen Torso die Züge einer neuen Auffassung sind. Ähnlich wie die ungewöhnliche Verarbeitung des Sujets Italienische Städte ist auch Macháčeks Umgang mit dem Thema Landschaft völlig eigenwillig. Dabei bleibt er nicht an alten bewährten Formen verhaftet, wie er im Übergang von ursprünglich statischen Arbeiten aus dem Zyklus Krížovice zu Schroffen Landschaften und Flatternden Landschaften beweist, mit dem er manche eingebürgerten Vorstellungen über Charakter des Kunstwerks oder Verarbeitung eines Themas als solche überwindet. Noch ein weiteres grundsätzliches Motivgebiet von Zdeněk Macháček hängt mit der Natur zusammen. Seine Phantasie konzentriert sich nicht mehr auf Landschaften, sondern auf Baumstämme: zum Himmel hinaufragend - Teil der Natur, Symbol, Zeichen zugleich. Hochragende schlanke Waldbäume im säuselnden Wind, der auch Macháčeks Windlandschaften flattern ließ, erinnern an mächtige Pfeifen. Das hat der Bildhauer sensibel wahrgenommen und dargestellt: Nachdem ein Baumstamm ausgehöhlt worden war und an Gewicht verloren hatte, machte er in verschiedenen Höhen Löcher darin, die die vertikale Öffnung der Säulenform ergänzten. In neuer Gestaltung wiederholte sich hier das Prinzip einer Hülle um leeren Raum herum, das der Bildhauer vorher in den zerbrechlichen Formen der Welten der Stille mit Erfolg benutzte. Ähnlich wie in den vorangehenden Schaffensperioden bilden Macháčeks Arbeiten auch jetzt thematische Zyklen, deren Titel das Hauptthema bezeichnen und auf poetisches Wahrnehmen hinweisen. Nicht nur die Vorstellung riesengroßer Naturpfeifen, sondern auch die Assoziation zur hochreckenden Vertikalität gotischer Kirchenräume beeinflusste dann den Künstler beim Meistern der Objekte, die er Waldkathedralen nannte. Ihre Höhe überragt mehrmals das menschliche Maß und in ihren Wänden, d. h. im Holzmantel, sind neben Seitenöffnungen auch Vitragen einkomponiert, die das Bild der Kathedralen vollenden.

Das Motiv der Waldgiganten ist nicht der einzige Themenkreis Macháčeks in den achtziger Jahren. Den Gegenpol zu Waldkathedralen stellen Muscheln dar. Nach mehreren Jahren kehrt der Kontrapunkt von Vertikalen und rundlichen Formen wieder, der bereits früher angedeutet wurde. Diesmal jedoch ist der Kontrast gesteigert und in zwei selbständigen Sphären behandelt, wobei jede auf ihre Weise, auf ältere Arbeiten zurückgreifen. Die Muscheln können an die einstigen Welten der Stille erinnern, obwohl sie im Rauminhalt ausgefüllt sind und der Gegenstand nur durch eine klaffende Spalte unterbrochen ist. Der tiefere Sinn, den der Autor den graziö- 
sen Muschelformen zumutet und den er auch durch die Bezeichnung Unsere Muscheln betont, entspricht dem häufigen Lebensgefühl einsamer Menschen, die in sich eingeschlossen und in ihrer Einsamkeit gefangen sind.

In den Zyklen Verwüstete Landschaften und Zu Tode gequälte Bäume hat sich Macháčeks Material Holz verändert: von außen betrachtet war es nicht mehr kompakt wie früher, kein fester Werkstoff, sondern ein halbzerfallener, zerbrochener, verbogener. Hinzu trat eine weitere, und zwar entscheidende Wandlung: als wäre die Holzmaterie erleichtert und die Gravitation aufgehoben. Zum zentralen Thema wurde wieder die Menschenfigur, nur diesmal in einer neuen, mehr entmaterialisierten Weise, die den Menschen nicht mehr am Fliegen hindert (Flug über der Landschaft, 1992, Überflug, 1994, Taumel des Flugs, 1994, Glückseliger Flug, 1997, Ausgelassener Pegasus mit Muse, 1997, u. a.).

Ekstase und Poesie des Flugs und der Sehnsucht finden bei Zdeněk Macháček ihren Gegenpol in Werken, die von einer andersartigen Poesie erfüllt sind - in Plastiken, die sich in mancher Hinsicht volkstümlicher Auffassung nähern und zum Lächeln bringen. Seit Anfang der neunziger Jahre gestaltete der Künstler originelle Holzbrunnen, Gefäße, bei deren Formgebung und Außendekor er Erfahrungen und Einfälle einsetzte, die er bei Arbeiten an Vasen für das Brünner Messegelände oder Behältern für den Zwinger in Jihlava gesammelt hat. Aus dem Inneren der Brunnen taucht der Rundkopf eines eigenartigen Wasserspeiers auf. Nahe Verwandte der Wasserspeier sind Pfiffikusse, die statt aus Wasser hinter Balken hervorspähen. Um 1995 wurde Zdeněk Macháček von der Vorstellung eines beflügelten Engels fasziniert, die er in einer Reihe von schwebenden oder nur leicht die Erde berührenden Figuren realisierte. Seine Engelwesen haben zerbrechliche Gliedmaßen, einen länglichen, in einem Gewand verhüllten Rumpf und strahlenförmig struppiges Haar. Die Figuralwerke stellen fast körperlose, entmaterialisierte Wesen dar, die allerdings nicht geschlechtslos sind. Außer deutlichen Unterscheidungsmerkmalen - Kopfhaar und Brüste bei Frauenakten, Geschlechtsteile bei Männerakten - vermitteln sie erotische Sehnsüchte, ebenso wie in den Werken Taumel des Flugs, Überflug, Flug über der Landschaft, Pferderitte und anderen. Liebende amüsieren sich übrigens öfter auf dem Pferderücken. Ähnlich wie bei Liebespaaren auf dem Pferderücken ist das Thema der Liebe in der Serie Oh, die himmlische Liebe durch aufgeregte Bewegung geprägt: Die Liebenden schmiegen sich aneinander in verschieden gespannten Positionen; in der Ekstase schweben sie im Raum, ob die Figurengruppe hängt oder an einer langen Stange gehalten ist. Die Aufmerksamkeit, die Zdeněk Macháček diesem Sujet widmet, wurde in der Mitte der neunziger Jahre zum großen Teil von der Aufforderung Jaroslav Malinas, Professor an der MasarykUniversität, zur künstlerischen Teilnahme an einem Projekt genährt. Es handelt sich um das Vorhaben Der Kreis des Fingerringes: Weltgeschichte der Sexualität, Erotik und Liebe von den Anfängen bis zur Gegenwart - dargestellt im realen Leben, in der Belletristik, der Bildenden Kunst und in Kunstwerken vom Inhalt des vorliegenden Buches inspirierter tschechischer
Maler und Bildhauer. Dieses umfangreiche Projekt befasst sich mit dem Thema „Liebe im Leben und in der Weltliteratur, in Darstellungen durch Hände und Herzen tschechischer Maler und Bildhauer" und hat zum Ziel, Publikationen herauszugeben und Ausstellungen zu veranstalten. In den Jahren 1996-2008 hat Zdeněk Macháček für das genannte Projekt einige Dutzende von Plastiken und ein dreidimensionales Emblem Der Kreis des Fingerringes geschaffen. Auch nach seinem achtzigjährigen Jubiläum 2005 hat er dieses Thema nicht verlassen.

Die Tendenz Macháčeks zu immer schlankeren Formen kam auch in den Plastiken Botschaft aus dem All (1990) und insbesondere Wachstum (1990) zum Ausdruck, in deren abstrakter Form sich die Inspiration von Naturkräften und Erscheinungen belebt. Diese Anregung kehrt im Macháčeks Werk in verschiedenen Variationen immer wieder. Eine besondere Form erhielt sie in der Serie Verwüstete Landschaft (1991). Für einzelne Objekte des Zyklus wurden augenfällige, ungleichförmige, teilweise verfallene und beschädigte Klötze ausgewählt. Die Verwüstung unterstützte Macháček auch mit Hilfe von Schwefelsäure und erreichte so eine starke Mementowirkung, ebenso in der Plastik Halbwertszeit (1991). In unterschiedlicher Weise setzte Macháček seine Ideen in den Plastiken $Z u$ Tode gequälter Baum (1992) und $\mathrm{Zu}$ Tode gequälte Bäume (1992) um: Das eine Mal findet er zur Darstellung des Kruzifixes, im anderen Falle stellt er eine Gruppe von schlanken, kahlen, rindenlosen Baumtorsos mit aufragenden Stümpfen zusammen.

Die in den Zyklen Verwüstete Landschaften und $Z u$ Tode gequälte Bäume vollzogene Veränderung hat den Figuren Macháčeks das Fliegen beigebracht. Während Anfang der neunziger Jahre seine fliegenden Figuren noch etwas gewichtig waren, berührten in der zweiten Hälfte der neunziger Jahre die mit Bewegung geladenen fragilen Fliegenden kaum die Erde. Zum Fliegen angepasste Figuren haben sich von ihrer Trägerin - der Landschaft - völlig losgelöst und ruhten nicht einmal mehr auf dem Pferderücken. Nur leicht verankert schwammen sie in den Lüften, die Horizontale ihrer Körper leicht gebogen, den Kopf nach oben gerichtet. Nicht nur einzelne Figuren, sondern auch Figurengruppen ragen zum Himmel empor.

In den letzten Jahren war es wieder die Landschaft, die die Imagination des Künstlers beherrschte. Nach mehr als zwanzig Jahren fand er eine neue Ausdrucksweise für das Motiv, das nicht nur in seine Kunst, sondern auch in sein Leben eindrang und beides beeinflusste. Unmittelbar nach der Schaffensperiode, die im Zeichen der zerbrechlich erscheinenden, schwebenden, unerfüllte menschliche Sehnsüchte verkörpernden Figuren stand, wandte sich Macháček zu materiellen, fest greifbaren Darstellungen eines seiner ihm nächstliegenden Motive - der Landschaft. Die Landschaften von 2003 und jüngere sind gegenüber den dreidimensionalen Schroffen Landschaften oder den Windlandschaften von 1980 eher flacher. Sie gehen aus der Form einer nicht sehr dicken Holzplatte hervor, deren Gestaltung manchmal in leichten Beulen die Plastizität nur gering andeutet. Das künstlerische 
Schaffen der letzten Jahre könnte bei Macháček eine Weiterentwicklung der Themen Landschaft und Erotik vorzeichnen, die ihn wohl nie losließen. Es kann aber auch in ziemlich unterschiedliche Sphären münden, die an jeweilige Motive nur entfernt erinnern. Macháček könnte auch auf einen völlig neuen Weg aufbrechen, wie es bei ihm mehrmals der Fall war .

Zdeněk Macháček veranstaltete mehr als vierzig Einzelausstellungen und nahm an rund sechzig Kollektivausstellungen im In- und Ausland teil: Biel (Schweiz), Blansko, Boskovice, Brno, Bystřice nad Pernštejnem, Hörle (Schweden), Kř́žovice, Perugia (Italien), Praha, Sharjah (Vereinigte Arabische
Emiraten), Wien (Österreich), Ždár nad Sázavou u. a

Macháčeks Werke sind in einheimischen und ausländischen Galerien und Museen vertreten, seine Plastiken befinden sich im Freien an vielen Orten in Tschechien, in der Slowakei und in Schweden, manche wurden zum Bestandteil einiger Dutzend architektonischer Interieure.

Eine ausführliche Beschreibung des Lebens und der Werke Zdeněk Macháčeks bringt die Monographie: Dvořáková, Nina - Malina, Jaroslav, Zdeněk Macháček. Brno: Akademické nakladatelství CERM, 2005.

(Übersetzung von Alena Opletalová) 